\title{
走行列車荷重を利用したRC鉄道高架橋の 部材振動の同定と動的挙動の把握
}

\author{
松岡 弘大 1 ・貝戸 清之 2 ・渡辺 勉 3 ・曽我部 正道 4 \\ 1学生会員 大阪大学 大学院工学研究科 地球総合工学専攻（†565-0871 吹田市山田丘2-1） \\ E-mail: k-matsuoka@civil.eng.osaka-u.ac.jp \\ 2正会員 大阪大学准教授 大学院工学研究科 地球総合工学専攻（同上) \\ E-mail: kaito@ga.eng.osaka-u.ac.jp \\ 3 正会員 公益財団法人鉄道総合技術研究所 鉄道力学研究部（广185-8540 国分寺市光町2-8-38） \\ E-mail: tsutomuw@rtri.or.jp \\ 4正会員 公益財団法人鉄道総合技術研究所 鉄道力学研究部（同上） \\ E-mail: sogabe@rtri.or.jp
}

\begin{abstract}
列車の急速な高速化に伴い, $\mathrm{RC}$ 鉄道高架橋, およびその構成部材においても, 共振の発生とこれに伴 う構造物音への対応が必要となってきている。本研究では，構造物音の評価や予測に不可欠なRC鉄道高 架橋の部材振動特性を明らかにするために, 実際のRC桁式高架橋とRCラーメン高架橋のスラブ部材を対 象とした列車走行試験を行い，振動特性を同定した。これにより，RC桁式高架橋では130Hz付近で中間ス ラブ， RCラーメン高架橋では $50 \mathrm{~Hz}$ を超える周波数帯域で同じく中間スラブの局所的な部材振動モードが 存在することを確認した。 さらに，これらの部材振動モードは車軸間隔との高次共振により列車走行時に 卓越成分を形成することを実証的に明らかにした。
\end{abstract}

Key Words : local member vibration, passing train load, dynamic properties, identification, field testing

\section{1. はじめに}

鉄道橋において，列車の高速走行に起因する共振 現象は極めて重要な工学的課題である ${ }^{1)-3)}$. 鉄道橋 の共振現象は，多数車両で編成される列車の走行荷 重が周期性を有する加振源となるために, 列車速度 の増加とともに橋梁 - 高架橋 (以下, 高架橋) の固 有振動と近接することによって発生する ${ }^{4), 5)}$. しか し，これらは列車走行時に生起する現象であるため に, 走行列車荷重が作用する状況の下で, 高架橋の 固有振動数や振動モード形といった振動特性を把握 することが重要となる.

特に，高速鉄道は継続的かつ急速な速度向上を果 たしており 6),7), 比較的単純な橋梁の全体 1 次曲げ の共振現象だけでなく, より局所的で複雑な部材レ ベルの共振現象の発生可能性も指摘されている ${ }^{8), 9)}$. 部材レベルでの共振は, 部材の動的応答を増大させ るだけでなく, 鉄道騒音の一種である構造物音の音 源となる. 構造物音のエネルギーは一般的に列車速
度に対して 2～3 乗程度の依存性を有するために ${ }^{10)}$, 列車速度が $300 \mathrm{~km} / \mathrm{h}$ 以上となる場合には部材レベル での共振が構造物音の発生原因となることが懸念さ れる 10),11). したがって，これまで構造物音が問題 となることが少なかった鉄筋コンクリート高架橋

(以下，RC 高架橋），およびその構成部材におい ても構造物音への対応が必要となってきている ${ }^{12)}$. RC 高架橋は，盛土に代わる連続立体構造として， 高速鉄道路線で多用されていることから，RC 高架 橋における構造物音の顕在化は，今後の鉄道の高速 化にとって深刻な問題となる. しかしながら, 部材 単位に着目した振動特性に関する研究は蓄積が乏し い. 効率的な対策に必要不可欠な, 構造物音の音源 部材の振動モード形については，ほとんど解明され ていないのが現状である ${ }^{13)}$.

以上の問題意識のもと, 本研究では高速鉄道路線 を構成する RC 高架橋の列車走行時の部材振動特性 と，共振速度を明らかにすることを目的とする。は じめに，未知外力作用下における振動特性の同定手 


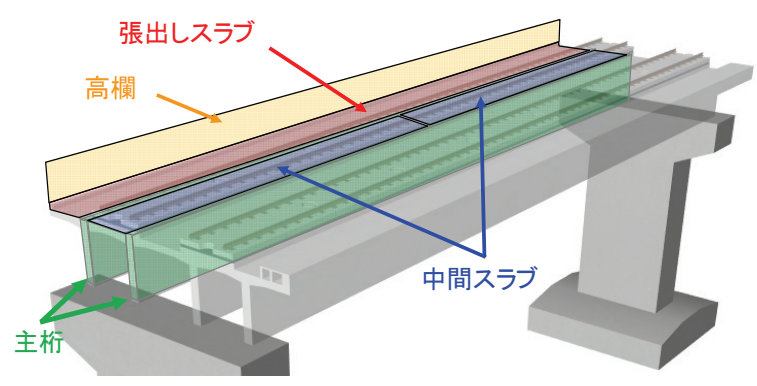

(a) RC 桁式高架橋

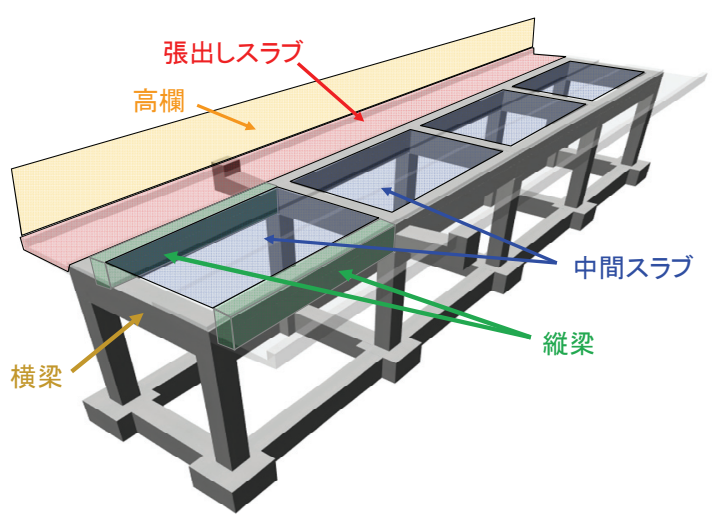

(b) RC ラーメン高架橋

図-1ＲC 高架橋と構成部材

法を列車走行時の橋梁の加速度応答に適用寸るとと もに，その信頼性をインパルスハンマーを用いた衝 撃加振試験との比較により検証する. また, 走行列 車荷重を加振源として用いた際に, 固有振動数と振 動モード形を高精度に同定するための経験的方法を 提示寸る.さらに, 同定結果を部材振動の簡易算定 式，および固有値解析により算出した理論值と比較 することで, 振動特性の妥当性を検証したうえで, これらの部材振動モードと走行列車との共振につい て分析する.

\section{2. 検討方法}

\section{(1) 対象橋梁}

近年建設されている高速鉄道路線では盛土代替と して高架橋が多く採用されている. 代表的な構造物 としては RC 桁式高架橋（図-1(a)），RC ラーメン 高架橋（図-1(b)）があげられ ${ }^{14)-16)}$, 本研究でもこ れら 2 つ高架橋形式を対象と寸る.

当該高架橋形式には，コスト低減と施工期間の短 縮を目的に，標準設計が導入されている ${ }^{14)-16)}$. 例 えば，図-1(b)に示寸当該路線の RC ラーメン高架橋 では, 層構造, 連続径間数, 背割り式とゲルバー式 などの項目を, 周辺環境区分, 雪荷重の有無, 地盤 や立地などの各条件に合わせて選定する. 標準設計 を用いた場合でも，部材断面は満たすべき保有性能 表-1＼cjkstart対象橋梁の構造諸元

(a) RC 桁式高架橋

\begin{tabular}{c|c}
\hline 構造形式 & $\begin{array}{c}\text { RC2 主 T桁式 } \\
\text { 単線高架橋 } \\
\text { 線支承, ゴム支承 }\end{array}$ \\
\hline 支承形式 & $\mathrm{G} 4$ \\
\hline 地盤種別 & $20.00 \mathrm{~m}$ \\
\hline 径間長 & $6.05 \mathrm{~m}$ \\
\hline 幅員 & $8.00 \mathrm{~m}$ \\
\hline 橋脚高さ & $24.0 \mathrm{~N} / \mathrm{mm}^{2}$ \\
\hline 設計基隻強度 & $25.0 \mathrm{kN} / \mathrm{mm}^{2}$ \\
\hline ヤング係数 & $269.8 \mathrm{kN} / \mathrm{m}$ \\
\hline 橋梁単位重量 &
\end{tabular}

(b) RC ラーメン高架橋

\begin{tabular}{c|c}
\hline 構造形式 & $\begin{array}{c}\text { 径間 RC ラーメン形式 } \\
\text { 複線高架橋 }\end{array}$ \\
\hline 基礎, 杭形式 & 連結基礎, 独立杭 \\
\hline 地盤種別 & G 2 \\
\hline 径間長 & $7.88+8.10+7.88 \mathrm{~m}$ \\
\hline 幅員 & $11.60 \mathrm{~m}$ \\
\hline 柱高さ & $10.00 \mathrm{~m}$ \\
\hline 設計基準強度 & $27.0 \mathrm{~N} / \mathrm{mm}^{2}$ \\
\hline ヤング係数 & $26.5 \mathrm{kN} / \mathrm{mm}^{2}$ \\
\hline 上部構造コンクリート単位重量 & $291.8 \mathrm{kN} / \mathrm{m}$ \\
\hline 柱コンクリート単位重量 & $27.0 \mathrm{kN} / \mathrm{m}$ \\
\hline 基礎コンクリート単位重量 & $44.2 \mathrm{kN} / \mathrm{m}$ \\
\hline \multicolumn{2}{|l}{}
\end{tabular}

により多少変化するが, 縦梁（図-1(b)中の緑色 部）や中間スラブ（青色部）は，設計を左右する列 車荷重が同一であること, 部材厚の決定要因である 柱間隔がほとんどの RC ラーメン高架橋で $8 \mathrm{~m}$ 程度 であることから，基本的には同様の断面となる傾向 にある。具体的には，中間スラブでは，部材厚 280mm の板部材が用いられている。 また, 張出し スラブ（赤色部）の部材厚に関しても，負担重量, 張出し長によりいくつかの組合せが存在するものの, 付根部で $430 \mathrm{~mm}$, 先端部で $200 \mathrm{~mm}$ の板部材が大多 数を占める傾向にある ${ }^{14), 15)}$.

一方, 図-1(a)に示寸 RC 桁式高架橋の標準設計で は，径間長とともに桁高が変化するが，中間スラブ, 張出しスラブの部材寸法は大きく変化しない，また， 場所打ちによる RC 桁の最長径間が $20 \mathrm{~m}$ であること や，橋脚建設などの経済的な理由から，RC 桁式高 架橋では径間長 $20 \mathrm{~m}$ の割合が高い ${ }^{14), 15)}$.

以上より，これらの高架橋の上部構造に対する 振動特性を精緻に把握することで, 既設の大多数の 橋梁・高架橋の部材振動に関する共通の知見を獲得 することができる. 具体的な振動計測対象として, 1）標準的な径間長 $20 \mathrm{~m}$ の RC2 主 $\mathrm{T}$ 林式の単線高架 橋, 2) 全長 $25 \mathrm{~m}$ の 3 径間連続 RC ラーメン形式の 複線高架橋を選定し，特に部材厚が薄く，大きな動 的応答が励起されやすいスラブ部材（中間スラブ, 
表-2 加振源の諸元

\begin{tabular}{|c|c|c|}
\hline 加振方法 & 加振源の諸元 & 加振回数 \\
\hline $\begin{array}{c}\text { インパルスハンマー } \\
\text { による衝撃加振 }\end{array}$ & $\begin{array}{c}\text { ハンマ重量 : } 5.5 \mathrm{~kg} \\
\text { 振幅レンジ : } 22 \mathrm{kN} \\
\text { 加振周波数範囲 : } 0 \text { 0 500Hz } \\
\text { 感度 : } 0.22 \mathrm{mV} / \mathrm{N}\end{array}$ & 各部材 4 点 × 3 回 \\
\hline 走行列車荷重 & $\begin{array}{c}\text { 車両編成 : } 10 \text { 両, } 16 \text { 両 } \\
\text { 最大軸重 : 13,200kg, } 12,200 \mathrm{~kg} \\
\text { 走行速度 : 156 269km/h }\end{array}$ & 各部材 6 8 本 \\
\hline
\end{tabular}

表-3 対象部材と計測点配置

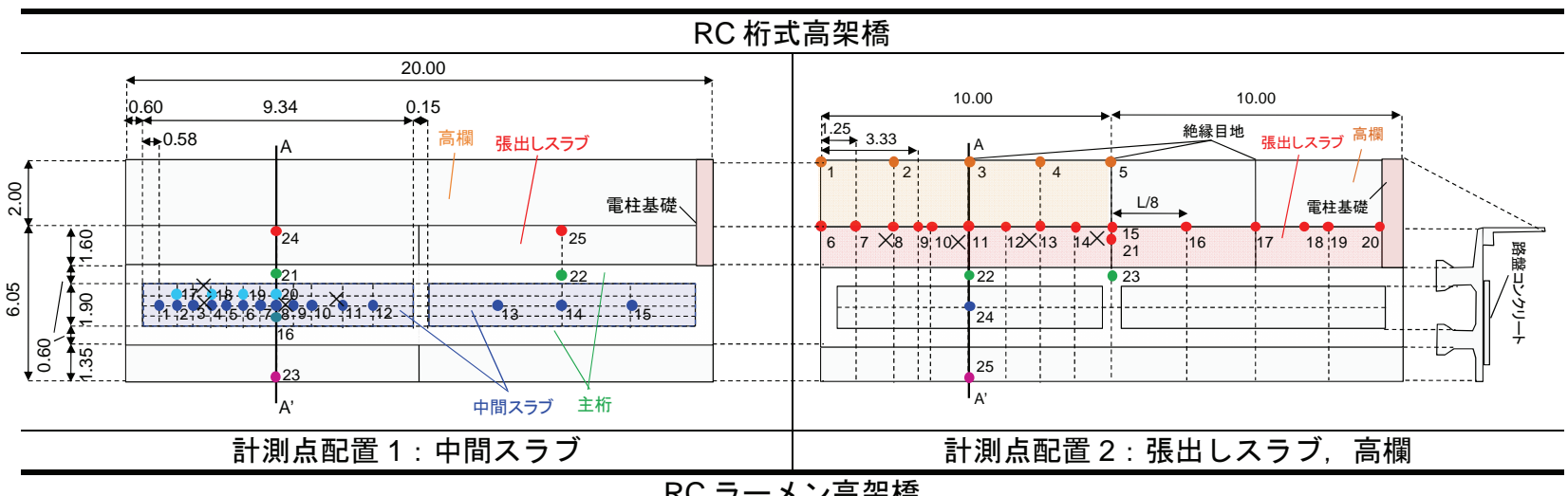

RC ラーメン高架橋

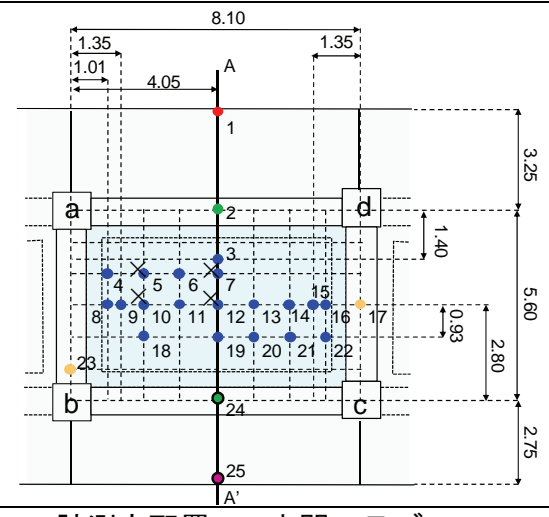

計測点配置 3 : 中間スラブ

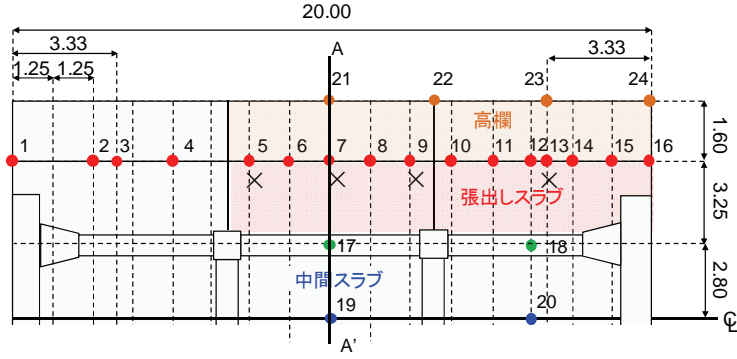

計測点配置 $4:$ 張出しスラブ, 高欄

・ : 計測点, $\times$ : インパルスハンマーによる衝撃加振位置, 単位 $: m$

張出しスラブ）を中心とする部材振動に着目する. 対象とした $2 つ の$ 高架橋の構造諸元を表-1に示す. RC 桁式高架橋は, 地盤種別 ${ }^{17)}$ が G4 と比較的軟弱 地盤に建設されており，支承にはゴム支承が採用さ れている。一方で, RC ラーメン高架橋は比較的堅 固な G2 地盤上に建設されている.

\section{（2）試験方法}

本研究では上述の高架橋を対象とした振動試験の 加振源として, 走行列車荷重を利用した（列車走行 試験）。また列車走行試験結果との比較を目的にイ ンパルスハンマーによる衝撃加振試験（インパルス ハンマー試験）も併せて実施した。これらの加振源 の諸元を表-2 に示す. インパルスハンマー試験で は, 人力により対象部材に衝撃加振力を加えること で振動を励起する． 1 つの部材に対して加振点を 4
点設け，加振点ごとに 3 回の計測を実施している. 一方で，列車走行試験では，当該路線を走行する高 速列車を加振源として採用した。走行列車は 10 両, もしくは 16 両の車両により編成される. スピード ガンにより計測した列車の走行速度は，ほとんどの 列車が約 $250 \mathrm{~km} / \mathrm{h}$ であったが， $150 \mathrm{~km} / \mathrm{h}$ 程度の列車 も一部で存在した。列車走行試験は各部材でそれぞ れ 6〜8 本の走行列車を利用して実施した.

\section{(3) 計測方法}

対象部材である中間スラブ，張出しスラブを中心 に計測点を多点配置した。計測点の配置状況，およ びインパルスハンマーでの衝撃加振位置を表-3に それぞれ示す. いずれも 25 台の加速度計により 25 点の計測点を設けている. 本研究では, 部材の高次 モード成分，特に振動モード形の把握を目的として， 
20 点程度を対象部材に割り当てるとともに，振幅 および周波数特性を相対的に比較するために他部材 にも 5 点程度の計測点を設けた．特に中間スラブは， 振動モード形を面的挙動として捉える必要性がある ために, 橋軸直角方向にも計測点を分散させて配置 した．また，いずれの高架橋においても張出しスラ ブは, 複数のスラブが連続的に組み合わされた構造 となっている。これらのスラブ間は絶縁目地となっ ており，鉄筋などによる構造的連結はなされていな い. 本研究では各スラブ同士が連成して振動するモ ードに着目することとし，すべてのスラブに計測点 を配置した。ささらに騒音の発生源となる可能性を有 する高欄にも計測点を 4,5 点配置している. なお, 高欄のみ線路直角方向の加速度を計測し, それ以外 は鉛直方向の加速度を計測した。

列車走行に伴い, 加速度振幅の増大が想定された こと， $200 \mathrm{~Hz}$ 程度までの高次モードを同定対象とし たことから加速度計として圧電型加速度計（感度： $6.42 \mathrm{pC} /\left(\mathrm{m} / \mathrm{sec}^{2}\right)$, 応答振動数 : $\left.1 \sim 7,000 \mathrm{~Hz}\right)$ を用い た. 各点で計測された加速度応答はサンプリング周 波数 $2 \mathrm{kHz}$ で $\mathrm{AD}$ ボードを介してノート PC に収録 される.このとき, $1 \mathrm{kHz}$ 以上の周波数成分はアン チエイリアシングフィルターにより除去した。

\section{（4）振動特性の同定手法}

本研究では, 計測した加速度応答に対して, クロ

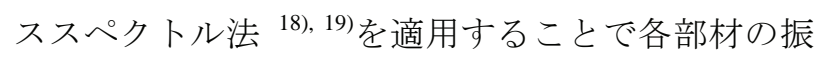
動モードを同定する. 手法の詳細は参考文献 19)に 譲るが, 読者の便宜を図るために概要を説明する.

当該手法では，はじめにすべての計測点 $(i=1,2, \cdots)$ の中から 1 つの計測点 $k$ を基準計測点として選定す る. 外力を白色雑音と仮定することで, 構造物の $n$ 次固有振動数 $\omega_{n}(\mathrm{~Hz})$ 付近において, 基準計測点 $k$ の モード振幅を 1 とする振動モード形 $\varphi_{i}\left(\omega_{n}\right)$ は,

$$
\varphi_{i}\left(\omega_{n}\right) \approx \frac{A_{i}\left(\omega_{n}\right) \cdot \overline{A_{k}}\left(\omega_{n}\right)}{\left|A_{k}\left(\omega_{n}\right)\right|^{2}}
$$

と近似できる。なお，式中， $A_{i}(\omega)$ は計測点 $i$ のフー リエスペクトルを, $A_{k}(\omega)$ は基準計測点 $k$ のフーリ エスペクトルを, $\bar{A}_{k}(\omega)$ は $A_{k}(\omega)$ の複素共役を表 す.これにより, 振動モード形の候補を抽出したう えで, 理論モード形を利用した MAC 検定 ${ }^{20)}$ に基づ いて, 固有振動数および振動モード形を同定するこ とができる，クロススペクトル法は，モード減衰比 を同定できない反面, 振動モード形を精度良く同定 できるという特徴を有している ${ }^{199}$ 。一方で, 高次 モードまでを対象とする場合には節となる計測点が
不明確となるために, 基準計測点の選定には留意が 必要である. 本研究では対象部材内の寸心゙ての計測 点を基準計測点候補とし, 同定可能なモード数と MAC 值を勘案したうえで，基準計測点を選定した。 なお，周期性を有する走行列車荷重を加振源と して利用することで発生する問題点として, 構造物 固有の振動モードとは異なる，加振周期に起因する 疑似モード ${ }^{20)}$ の混入があげられる. 走行列車によ る加振の影響により，構造物のスペクトルには，

$$
f_{v}=v / L_{v}
$$

で表される基本振動数 $f_{v}(\mathrm{~Hz})$ の整数倍で卓越成分が 形成されることになる ${ }^{1), 4)}$. 同定に際してはこの疑 似モードに留意する必要がある。なお， $v(\mathrm{~m} / \mathrm{sec})$ は 走行列車の速度, $L_{v}$ は車両 1 両の長さ $(\mathrm{m})$, もしく は車軸間隔 $(\mathrm{m})$ を表す。

\section{（5）部材振動の理論的算定方法}

同定結果の妥当性を検証するために, 理論式, お よび固有值解析により固有振動数を算出し, 同定結 果との比較を行う。

比較的単純な 1 次モードの固有振動数は, 既往の 研究 ${ }^{9)}$ でも適用されている構造力学公式集 ${ }^{21)}$ の理論 式に従い算出する. 式(3)に張出しスラブ 1 次モー ドを想定した片持ち梁の固有振動数算定式を, 式 (4)に全体 1 次モードを想定した単純梁の固有振動 数算定式を, 式(5)に中間スラブ 1 次モードを想定 した 4 辺単純支持, および固定支持の平板の固有振 動数算定式をそれぞれ示す.

$$
\begin{gathered}
\omega_{n}=\frac{1}{2 \pi \lambda^{2}} \sqrt{\frac{3 E I \cdot g}{\rho A(\mu+0.23)}} \\
\omega_{n}=\frac{1}{2 \pi \lambda^{2}} \sqrt{\frac{48 E I \cdot g}{\rho A(\mu+0.49)}} \\
\omega_{n}=\frac{k \pi}{2 a^{2}} \sqrt{\frac{E I \cdot g}{\rho \cdot h}}
\end{gathered}
$$

ここに, $\lambda$ は張出し長, 径間長 $(\mathrm{m}), E$ は部材のヤン グ係数 $\left(\mathrm{kN} / \mathrm{m}^{2}\right), I$ は部材の断面 2 次モーメント $\left(\mathrm{m}^{4}\right)$, $g$ は重力加速度 $\left(\mathrm{m} / \mathrm{sec}^{2}\right), A$ は部材の断面積 $\left(\mathrm{m}^{2}\right), \quad \rho$ は部材の単位重量 $\left(\mathrm{kN} / \mathrm{m}^{3}\right), \mu(=\mathrm{m} / \rho A \lambda), \quad m$ は（張出 しスラブ先端の高欄重量を意味する）集中重量 $(\mathrm{kN})$, $h$ は部材厚 $(\mathrm{m}), k(=\alpha \times b / a)$ は長辺, 短辺比率と支 持条件による係数で, $a$ は短辺長さ $(\mathrm{m}), b$ は長辺長 さ $(\mathrm{m}), \alpha$ は支持条件に応じた係数をそれぞれ表す. なお, 部材のヤング係数 $E$, 単位重量 $\rho$, 断面積 $A$, 部材厚 $h$ は設計值を用いる. $\alpha$ の詳細は文献 21)を 


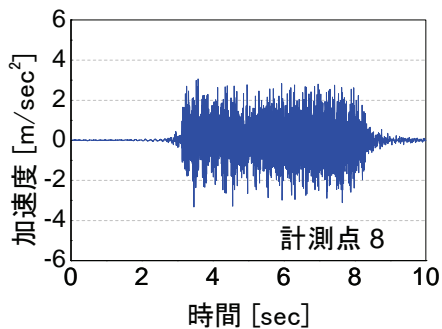

(a) 中間スラブ

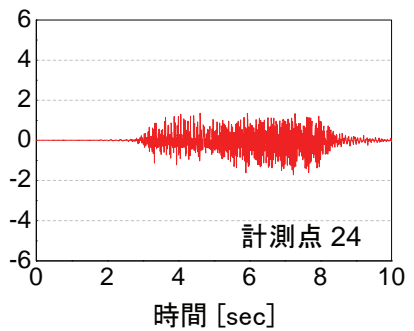

(b) 張出しスラブ

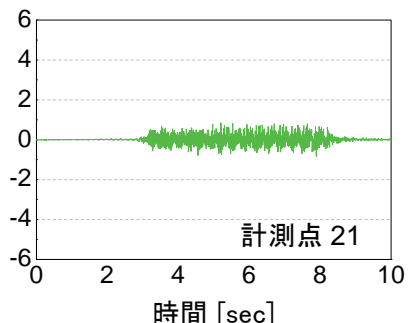

(c) 主桁

図-2 加速度応答（RC 桁式高架橋, 走行列車 : 16 両編成, $262 \mathrm{~km} / \mathrm{h}$, 下り )

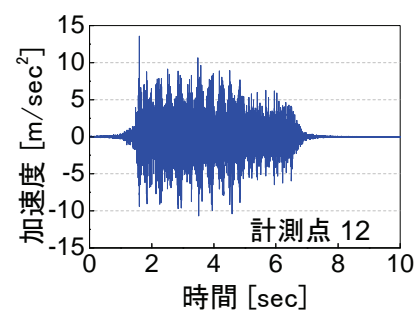

(a) 中間スラブ

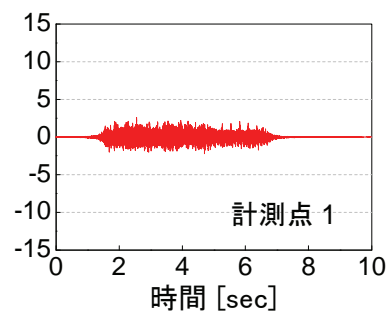

(b) 張出しスラブ

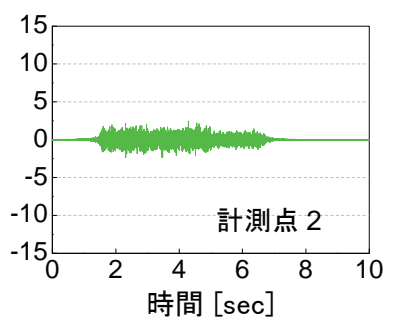

(c) 縦梁

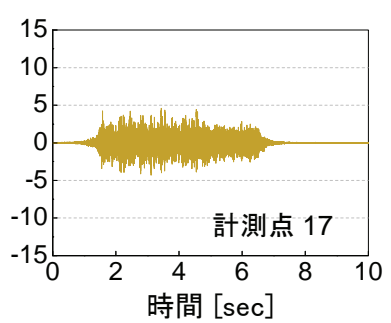

(d) 横梁

図-3 加速度応答（RC ラーメン高架橋 : 走行列車 : 16 両編成, $267 \mathrm{~km} / \mathrm{h}$, 下り )

参照されたい. 2 次以上の部材振動の固有振動数の 算定には固有值解析 ${ }^{22}$ を用いた。本研究では, 対 象部材のみの簡易な有限要素モデルを作成し, 固有 值解析を実施した。いずれの部材も三角形シェル要 素を用いてモデル化している. 境界条件は，中間ス ラブが 4 辺固定支持, 張出しスラブが 1 辺固定支持, および 1 辺固定，2 辺単純支持とした。 また，解析 モデルのメッシュ分割は, 対象部材の固有振動数と モード形状が再現できるように，最大でも $0.4 \mathrm{~m}$ 程 度としている. 中間スラブでは既往の研究 9)により 路盤コンクリートが固有振動数に影響を及ぼすこと が指摘されている。これを踏まえ, 文献 9)と同様に 路盤コンクリートの剛性を理論式, 固有值解析にそ れぞれ考慮している。 なお，路盤コンクリートの断 面は線路方向に一様と仮定したうえで設計值から算 出し，目地の影響は考慮していない。

\section{3. 振動計測と振動特性の同定}

\section{(1) 振動計測結果}

各橋梁で実施した列車走行試験結果の一例とし て, RC 桁式高架橋（計測点配置 1）で計測した加 速度応答を図-2（中間スラブ : 青, 張出しスラブ : 赤, 主桁 : 緑) に, RC ラーメン高架橋（計測点配 置 3）で計測した加速度応答を図-3（中間スラブ : 青, 張出しスラブ : 赤, 縦梁 : 緑, 横梁 : 黄) に, それぞれ示す. 図-2 に示す RC 桁式高架橋において， 走行列車荷重により励起される最大振幅は, 中間ス ラブで $3 \mathrm{~m} / \mathrm{sec}^{2}$ 程度であり, 張出しスラブ, 主桁と
比較して数倍大きくなっている．主桁の最大加速度 振幅が $1 \mathrm{~m} / \mathrm{sec}^{2}$ 程度であることと比較すると，想定 通り, 中間スラブで大きな振動が励起されているこ とがわかる。また，図-3の RC ラーメン高架橋にお ける最大振幅は，中間スラブで約 $14 \mathrm{~m} / \mathrm{sec}^{2}$ であり， 他の部材と比較して極めて大きい. 一方で，板部材 であることから比較的大きな振幅が予想された張出 しスラブよりも, 横梁の最大加速度振幅が倍程度大 きくなっている. RC ラーメン高架橋は複線橋であ るために, 列車の進行方向により主桁, 張出しスラ ブの最大振幅は 2 4m/ $\mathrm{sec}^{2}$ の範囲で変動するが，こ こで述べた基本的な傾向はいずれの列車通過時でも 同様であった。 なお， RC ラーメン高架橋では，横 梁の振幅が比較的大きいことを加味し, 横梁を対象 とした列車走行試験，および同定を実施したが，同 定したほとんどのモードが疑似モードであったこと から，記述は割愛する。

図-4, 図-5 にはインパルスハンマー試験により 得られた加速度応答の一例として, 計測点配置 1 の もとで計測点 8 付近を加振した際の RC 桁式高架橋 の中間スラブ（計測点 8），および計測点配置 3 の もとで計測点 12 付近を加振した際の RC ラーメン 高架橋の中間スラブ（計測点 12）の加速度応答を それぞれ示す。衝撃加振時に最大振幅を示し, 次第 に減衰していく自由振動応答を見て取ることができ る. 加振位置により最大振幅を示す計測点は異なる ものの，全ケースで同様の傾向を確認している.

つぎに，計測した加速度応答のパワースペクトル の一例として，RC 桁式高架橋の計測点配置 1 にお ける計測点 8 のパワースペクトルと RC ラーメン高 


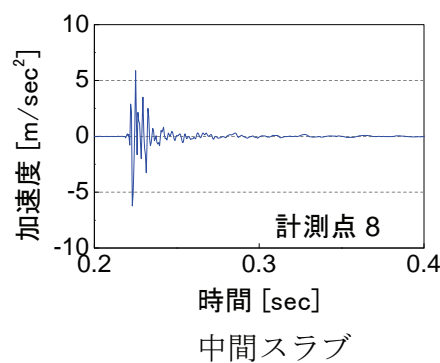

図-4 加速度応答

(RC 桁式高架橋：インパルスハンマー試験)

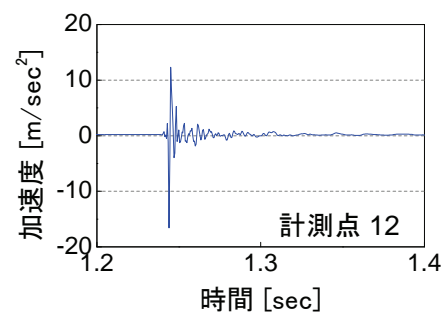

中間スラブ

図-5 加速度応答

（RCラーメン高架橋：インパルスハンマー試験）

架橋の計測点配置 3 における計測点 12 のパワース ペクトルを図-6, 図-7 にそれぞれ示す。各図(a)の 走行列車荷重は, 各図(b)のインパルスハンマー加 振と比較して, $200 \mathrm{~Hz}$ までのいずれの周波数帯でも 大きなエネルギーを有しているとともに，インパル スハンマー加振とは異なり，連行荷重に起因する無 数の線スペクトル状の卓越成分を確認することがで きる 18),19).

\section{(2) インパルスハンマー試験による同定結果}

列車走行試験とインパルスハンマー試験により得 られた加速度応答に対して，それぞれクロススペク トル法を適用することで，各橋梁の全体系と部材 (中間スラブ, 張出しスラブ，高欄）の固有振動数 と振動モード形を同定した。

\section{a) RC 椼式高架橋}

列車走行試験に先立って実施したインパルスハン マ一試験の同定結果（固有振動数, 変動係数, 振動 モード形，MAC 值）を表-4，表-5 に示す. なお， MAC 值は 1 に近いほど理論モード形に近い形状を 有していることを意味する. 各モードの振動モード 形は，同時に計測を行った他部材も記載し，モード 振幅の最大值が 1 となるように基準化している. 同 表中には橋軸方向だけでなく, 橋軸直角方向として 表-3 中の A-A'断面の振動モード形を記載している. また，凡例は紙面の都合上，最初のモードにのみ記 載する。表-5 の高欄に対するモード振幅（橙三 角）は外側への加速度を正とした線路直角方向のモ
一ド振幅を表している。さらに，変動係数は全 12 回のインパルスハンマー試験の固有振動数の標準偏 差を平均で除した值を表す。なお，本研究では，表 -4，表-5 中に示すように，各部材で同定された振動 モードをモード 1 ，モード 2 というように，固有振 動数の低い順に，便宜的に定義して示すとともに， その後に各振動モードに対する工学的な解釈（例え ば，中間スラブ 3 次など）を加えることとする。ま た，*の付いている振動モードはインパルスハンマ 一試験と列車走行試験で同一の振動モード形が同定 されている振動モードを表す。これらの表記は以降 も同様とする.

中間スラブを対象とした場合では 3 種類, 張出し スラブと高欄を対象した場合では 5 種類の振動モー ドが同定可能であった．特に，中間スラブのモード $3(131.1 \mathrm{~Hz})$ は橋軸方向に梁の 6 次モードを示して いるが，他の部材のモード振幅が 0 に近いことから， 中間スラブのみが卓越する部材固有の振動モードで あると考えられる。当該橋梁は 2 枚の中間スラブで 構成されているため, 中間スラブ 1 枚当たりでは梁 の 3 次モードである. 張出しスラブでは，モード 4 のように $9.1 \mathrm{~Hz}$ と比較的低次であっても部材振動が 励起されていることがわかる. 張出しスラブは電柱 基礎により桁端部の境界条件（支承条件）が不明確 であったために，1 辺（主桁側）固定支持の場合の 理論モードの他に，1 辺（主桁側）固定，2 辺（桁 両端）単純支持の場合の理論モードも同定に用いた。 同定結果では $38.5 \mathrm{~Hz}$ のモード 8 で桁端部のモード 
表-4 インパルスハンマー試験による同定結果（RC 桁式高架橋：中間スラブ）

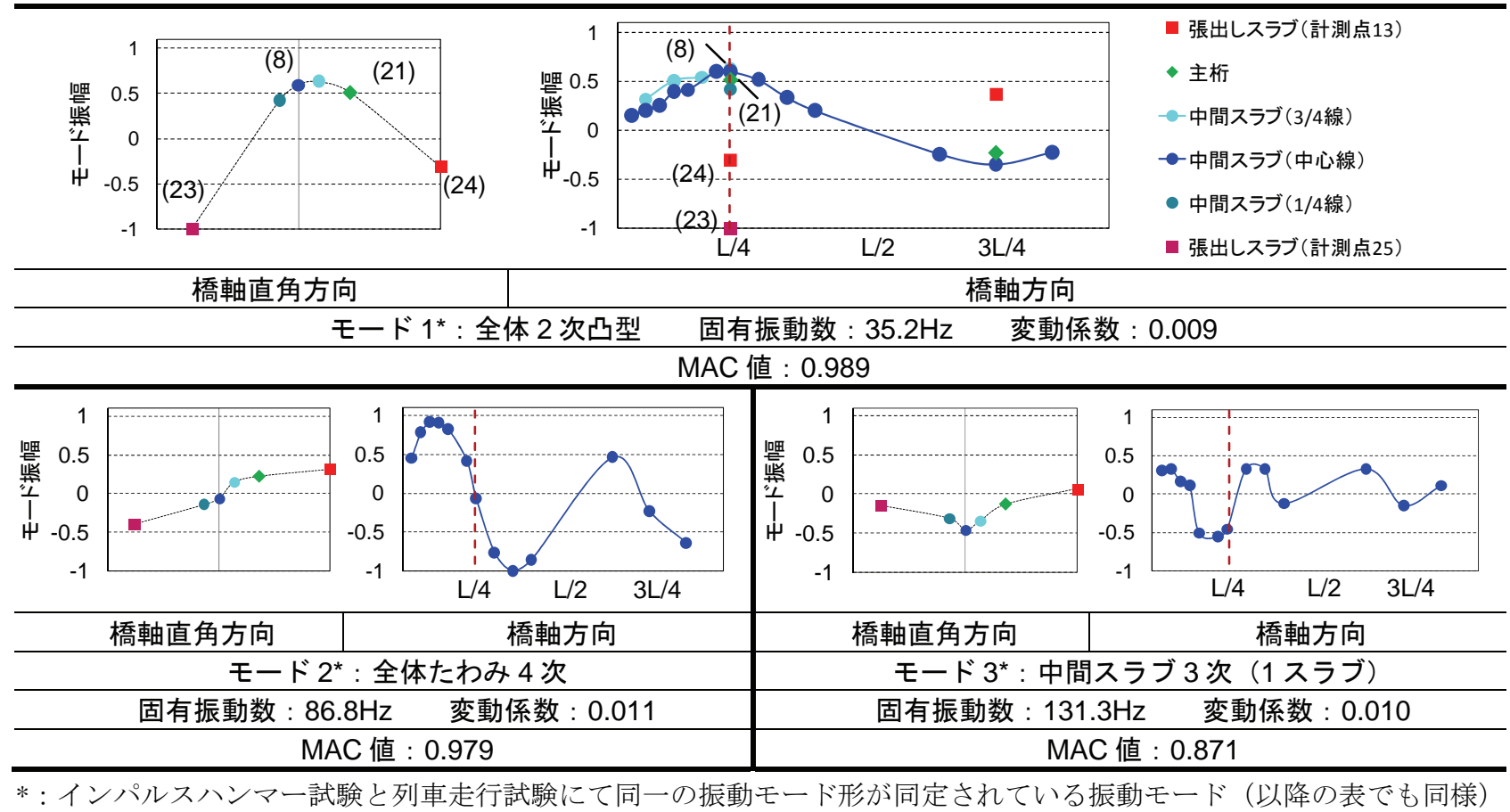

表-5 インパルスハンマーによる同定結果（RC 桁式高架橋：張出しスラブ，高欄）

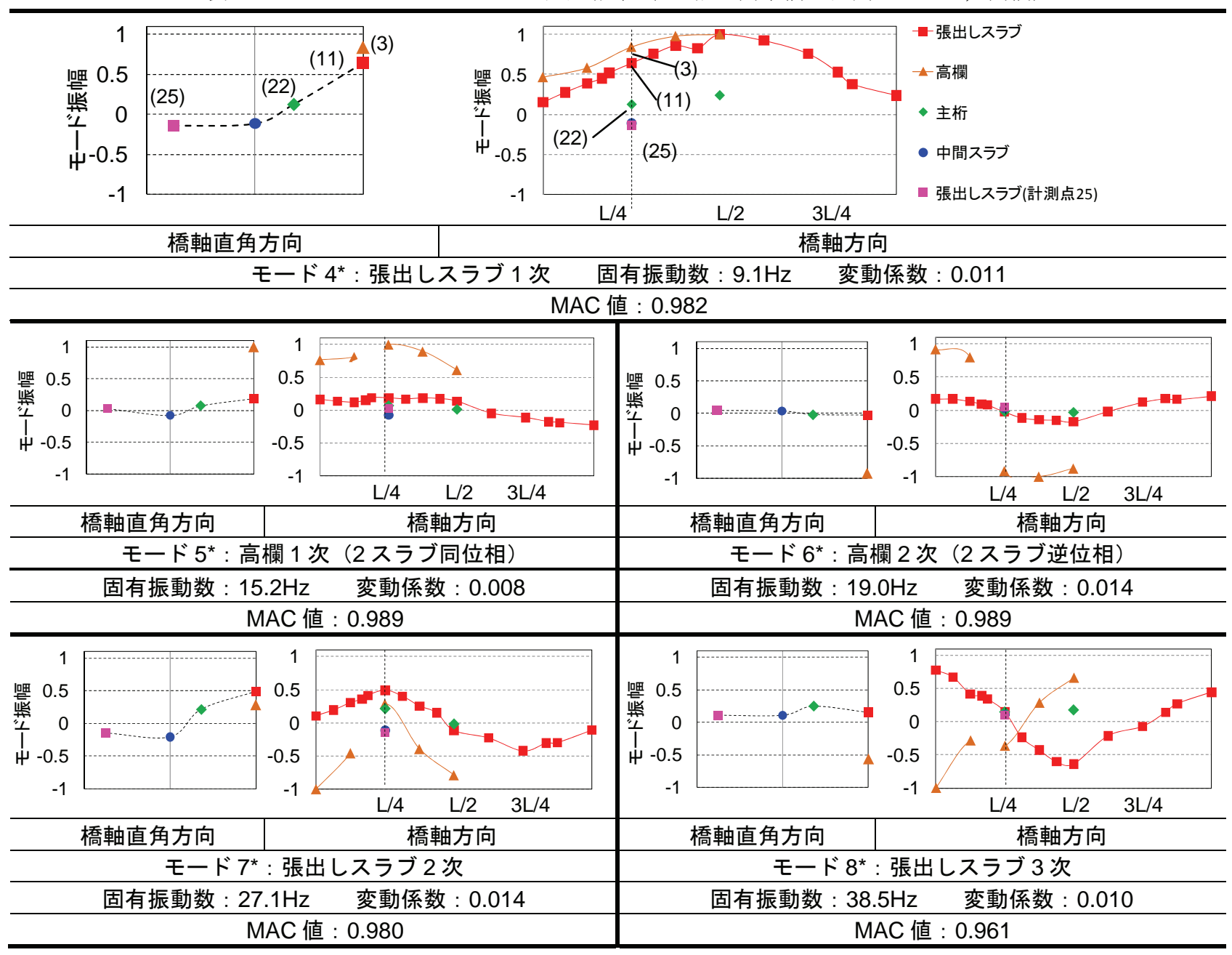


表-6 インパルスハンマー試験による同定結果（RCラーメン高架橋：中間スラブ）

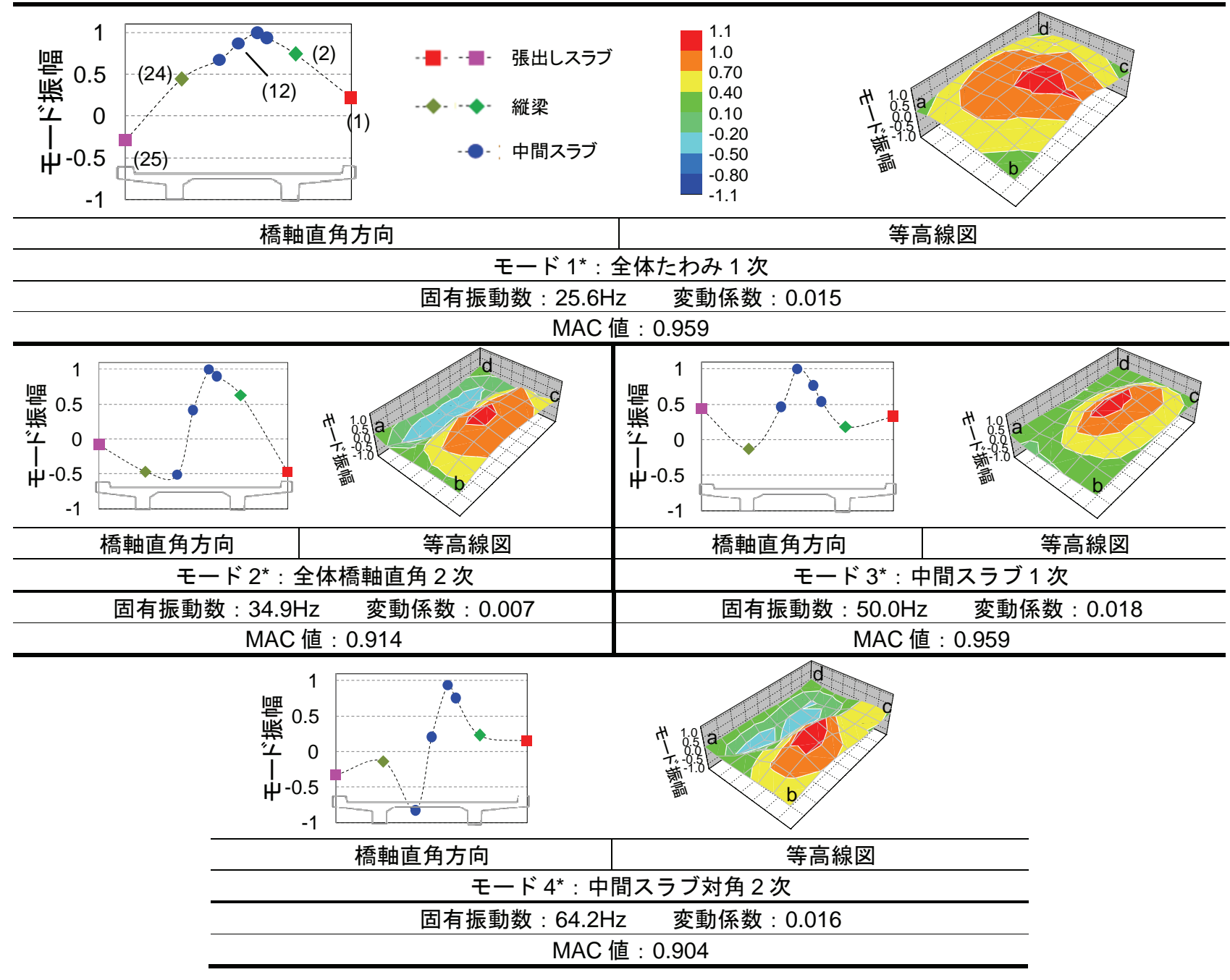

表-7 インパルスハンマー試験による同定結果（RCラーメン高架橋 : 張出しスラブ，高欄）

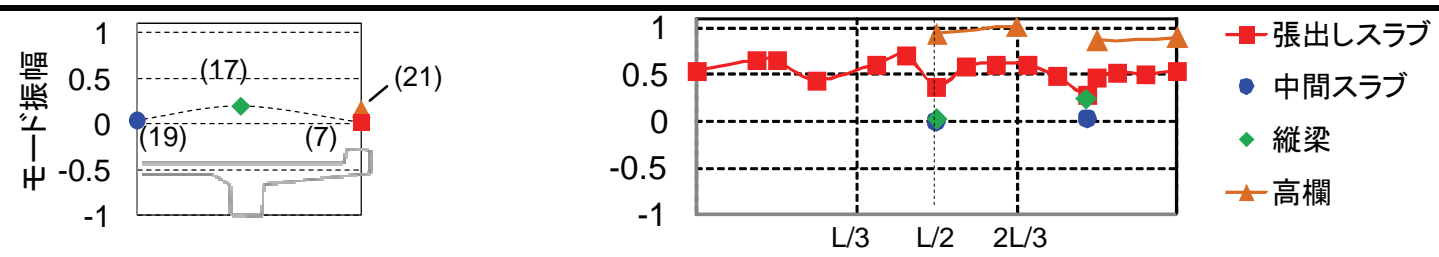

橋軸直角方向

橋軸方向

モード $5^{\star}$ : 張出し部 (張出しスラブと高欄) 2 次 固有振動数 : $13.8 \mathrm{~Hz}$ 変動係数 : 0.020 MAC 值 : 0.956

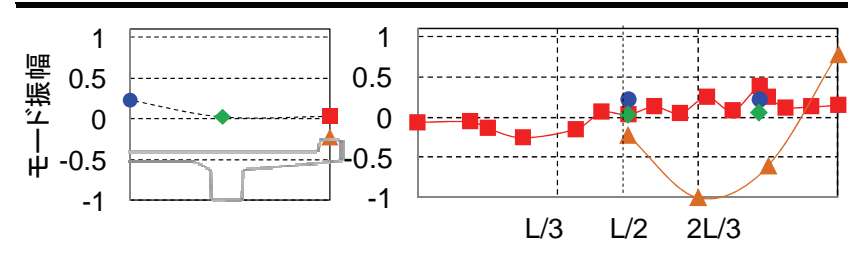

\begin{tabular}{l|r}
\hline 橋軸直角方向 & 橋軸方向 \\
\hline モード $6^{*}:$ 高欄 2 次
\end{tabular}

固有振動数: $19.0 \mathrm{~Hz}$ 変動係数 : 0.019 MAC 值 : 0.924

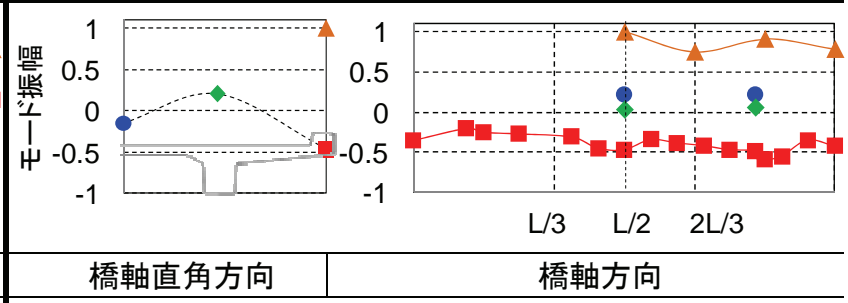

モード 7*: 張出し部単純振動

(張出しスラブと高欄が逆位相)

固有振動数: $30.0 \mathrm{~Hz}$ 変動係数: 0.016

MAC 值 : 0.982 
表-8 列車走行試験による同定結果（RC 桁式高架橋：中間スラブ）

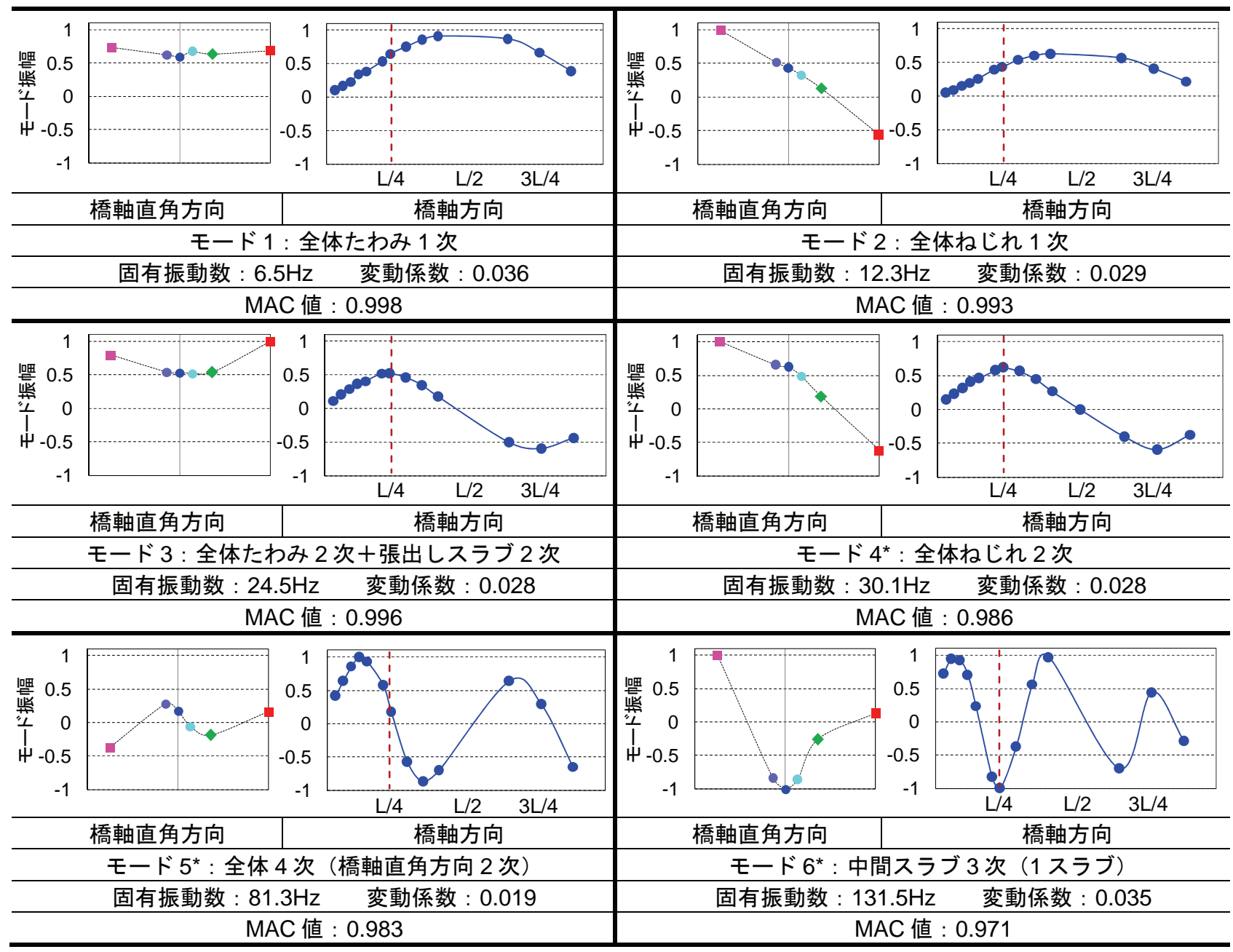

※計測点配置 2 と重複したモード 7 の掲載を省略している.

振幅が大きくなっている.

\section{b) RCラーメン高架橋}

$\mathrm{RC}$ ラーメン高架橋を対象として実施したインパ ルスハンマー試験の同定結果（固有振動数, 変動係 数, 振動モード形, MAC 值）を表-6, 表-7 に整理 する．表-6 の中間スラブは，振動モード形を面的 挙動として捉えるために等高線図で示している．等 高線図は中間スラブを橋軸方向に 8 メッシュ, 橋軸 直角方向に 6 メッシュで分割し, 各節点の座標と計 測点が一致する場合は実測值を, それ以外では周辺 の実測值で平均化することで座標值を補間している.

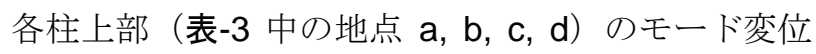
は 0 と仮定した. 同表中には, 表-3 中の A-A'断面 のモード形をともに記載している．表-7 には，張 出しスラブと高欄の同定結果を示している。橋軸直 角方向の振動モード形は表-3 に示す計測点配置 4 の A-A’断面を切り出したものである。また, 高欄の モード振幅（橙三角）は外側への加速度を正とした 線路直角方向のモード振幅を表している。
インパルスハンマー試験により当該橋梁では, 中間スラブで 4 種類, 張出しスラブ, 高欄で 3 種類 の振動モードが同定可能であった。中間スラブの振 動モードにおいては, モード $3(50.0 \mathrm{~Hz})$ とモード $4(64.2 \mathrm{~Hz})$ で, 縦梁のモード振幅が 0 に近いこと から，中間スラブのモード振幅が卓越した部材固有 の振動モードと考えられる. つぎに表-7 の張出し スラブと高欄を対象とした同定結果を見ると，各部 材のモード振幅からモード $6(19.0 \mathrm{~Hz})$ は高欄の部 材振動モードであると考えられる. 一方, モード 5

$(13.8 \mathrm{~Hz})$ とモード $7(30.0 \mathrm{~Hz})$ は, 張出しスラブ と高欄でともに一定のモード振幅が励起されており, 張出しスラブと高闌を合わせた張出し部としての振 動モードであると考えられる。

（3）列車走行試験による同定結果

a) RC 桁式高架橋

インパルスハンマー試験に続き, 列車走行試験に 基づいて固有振動数および振動モード形の同定を行 
表-9 列車走行試験による同定結果（RC 桁式高架橋：張出しスラブ，高欄）

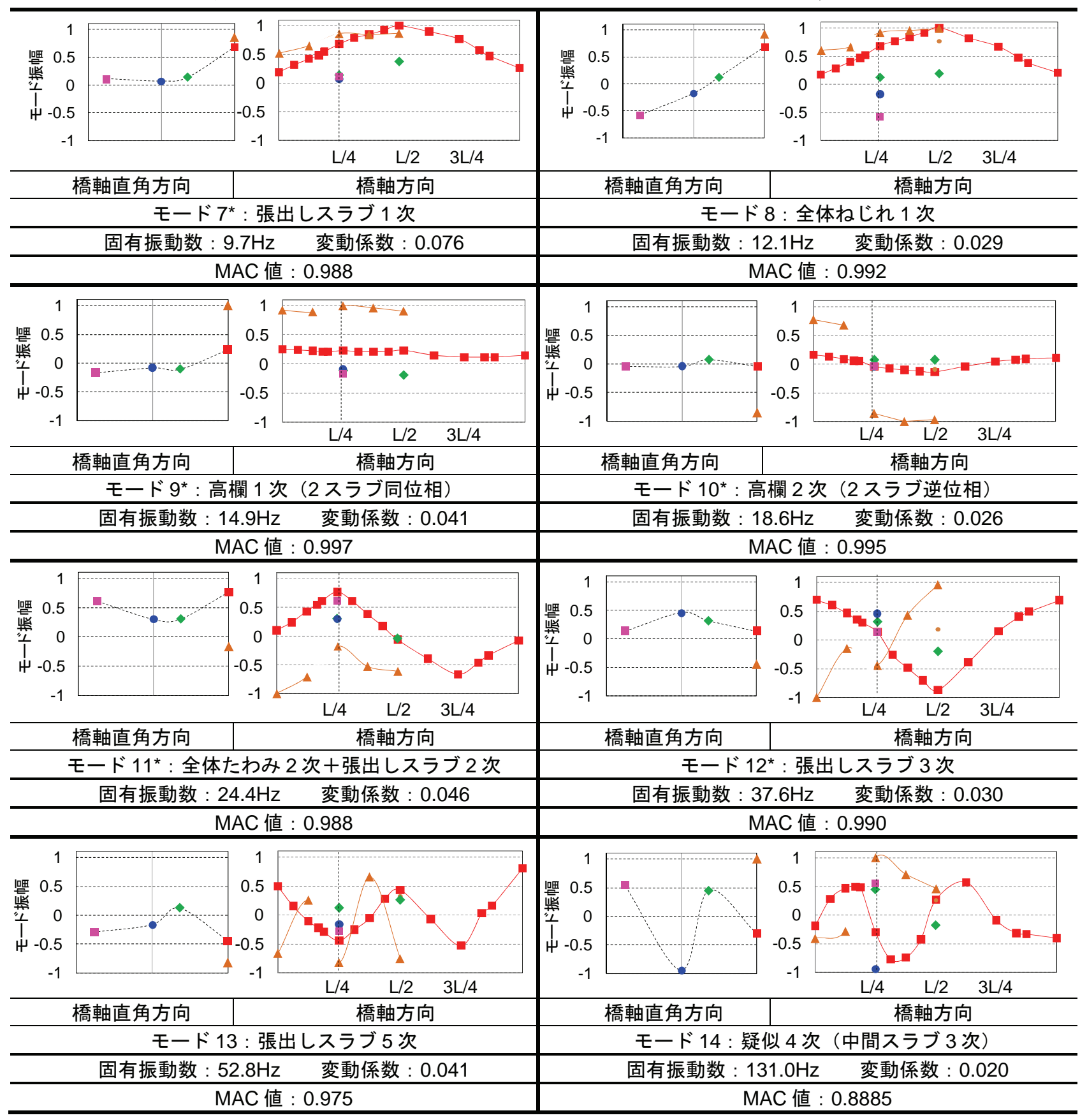

※計測点配置 1 と重複したモード 1 の掲載を省略している.

つた。 RC 桁式高架橋の同定結果を表-8，表-9 に整 理する。なお, 計測点配置 1 と計測点配置 2 でそれ ぞれ実施した 7 回，および 6 回の試験において，走 行列車の速度や進行方向等との間に有意な相関は確 認できなかった。また，モード 1 とモード 7 はいず れの計測点配置でも同定されたが，重複するために， 一方の表にのみ記載している.

列車走行試験では，計測点配置 1 で 7 種類, 計測 点配置 2 で 9 種類の振動モードをそれぞれ同定する ことができた。表-8 に示す中間スラブの同定結果 を見ると，他部材との関係から $131.5 \mathrm{~Hz}$ のモード 6
が中間スラブのモード振幅が卓越した局所的な振動 モードであることがわかる，先述したように，本橋 が 2 枚の中間スラブで構成されているために，各ス ラブの 3 次モードであると考えられる. なお，各ス ラブの 1 次， 2 次モードが同定できなかった理由と しては，中間スラブのアスペクト比があげられる。 当該橋梁の中間スラブは橋軸直角方向に比べ橋軸方 向に長い形状を有しているために，両方向でモード 形の半波の長さが大きく異なる 1 次， 2 次モードは 励起されにくく，同定には至らなかったと考えられ る.この他にも, インパルスハンマー試験では同定 
表-10 列車走行試験による同定結果（RC ラーメン高架橋 : 中間スラブ）

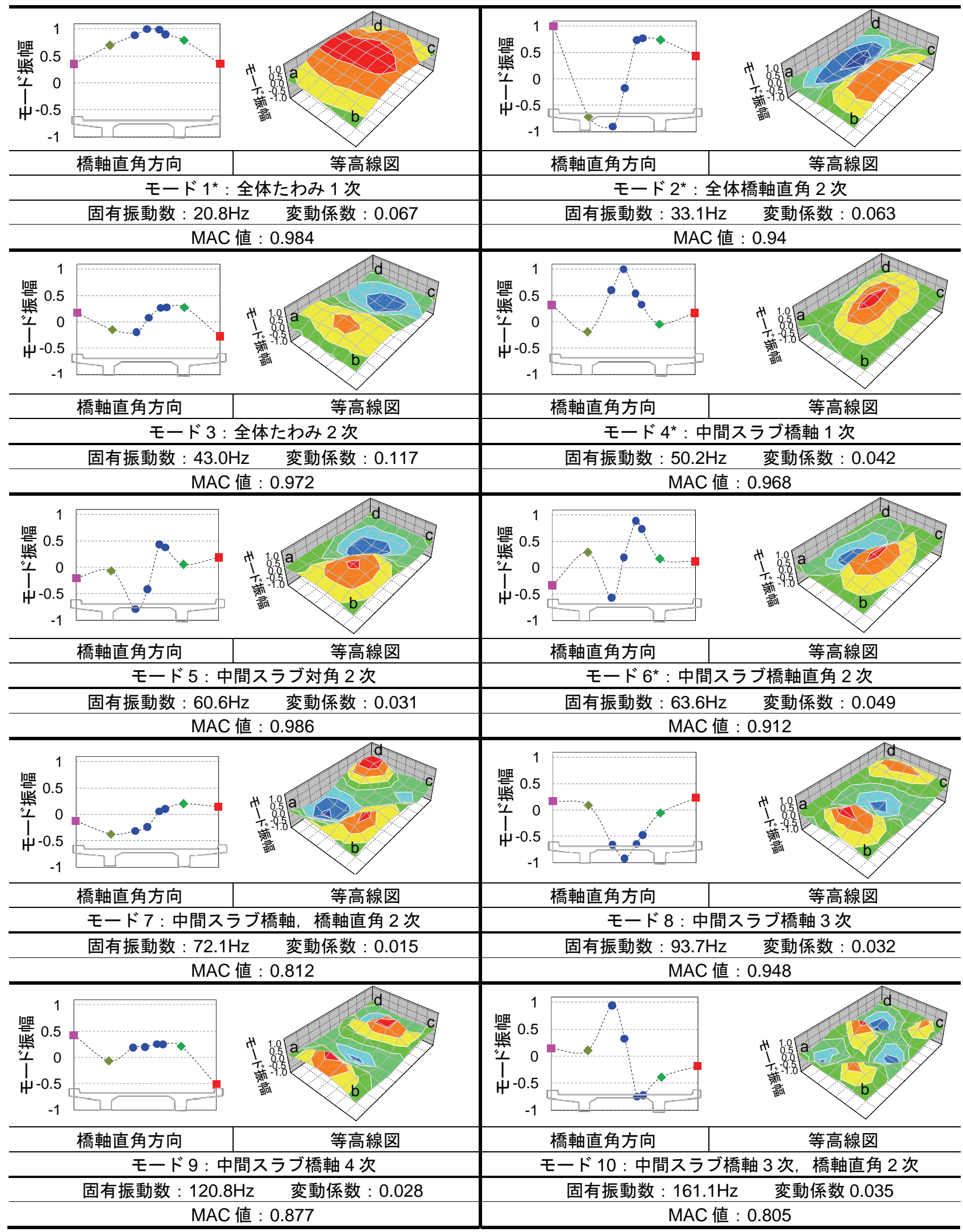

できなかった $30 \mathrm{~Hz}$ 以下の低次モードが同定可能で あった。これは，図-6のパワースペクトルに見ら れる両試験のエネルギー特性の相違, 図-2, 図-4の 加速度応答に見られる加振回数, および振動継続時
間の相違，に起因すると考えられる。

張出しスラブ，高欄においても，インパルスハ ンマー試験と同様に $9.7 \mathrm{~Hz}$ (モード 7） と比較的低 次で張出しスラブの部材振動モードが励起されてい 
表-11 列車走行試験による同定結果（RCラーメン高架橋 : 張出しスラブ，高欄）

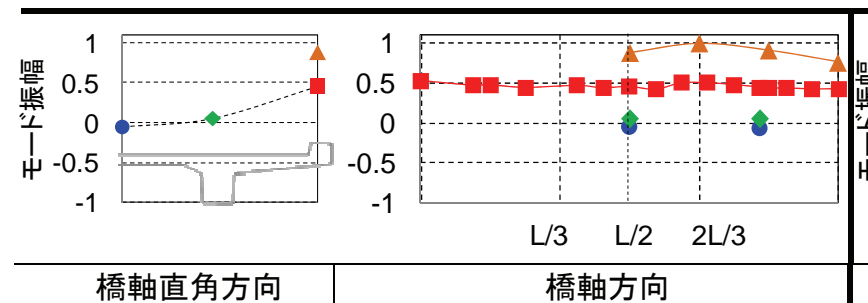

モード $11:$ 張出し部単純振動

(張出しスラブと高欄が同位相)

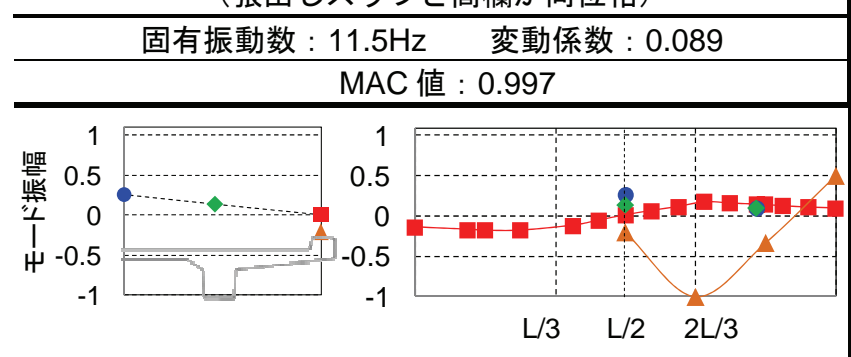

\begin{tabular}{c|r}
\hline 橋軸直角方向 & 橋軸方向 \\
\hline モード $13^{\star}:$ 高欄 2 次
\end{tabular}

\begin{tabular}{c}
\hline 固有振動数 : $20.8 \mathrm{~Hz} \quad$ 変動係数 : 0.018 \\
\hline MAC 值 : 0.942 \\
\hline
\end{tabular}

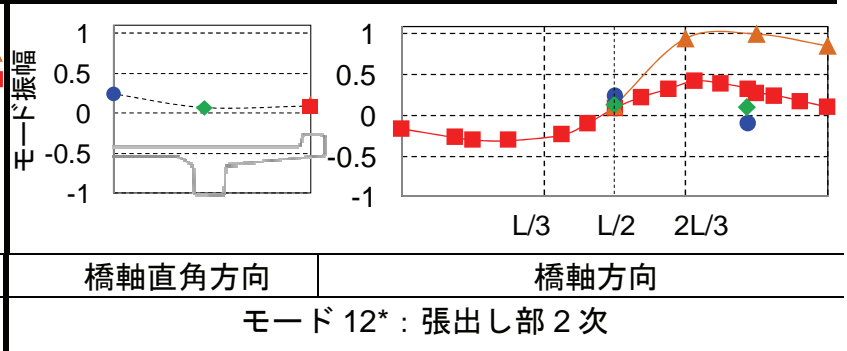

モード $12^{\star}$ : 張出し部 2 次

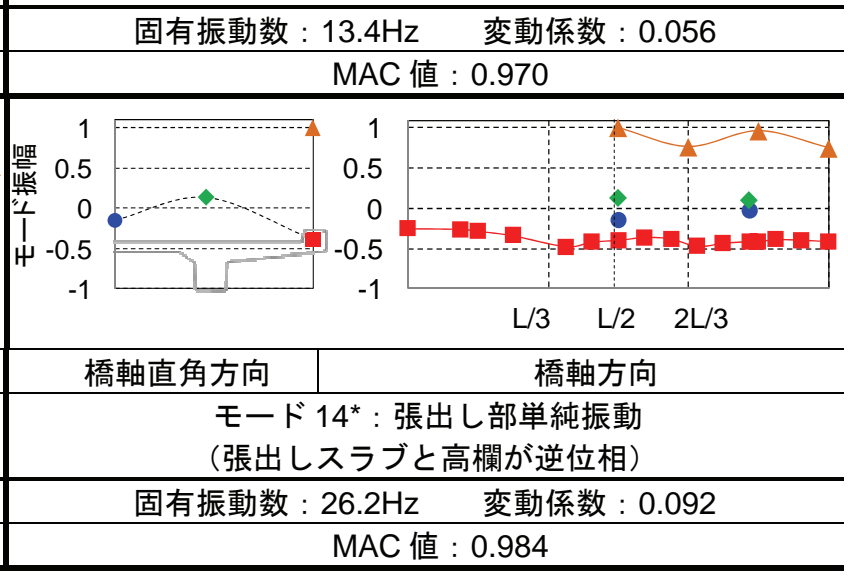

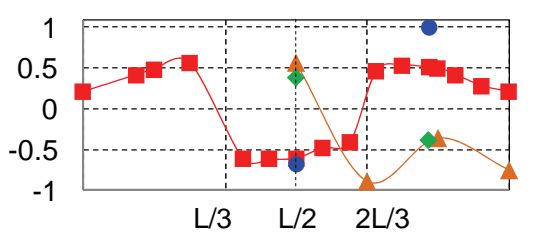

橋軸方向

\begin{tabular}{c}
\hline 橋軸直角方向 \\
モード $15:$ 各張出しスラブ 1次 \\
\hline 固有振動数 $: 41.3 \mathrm{~Hz} \quad$ 変動係数 : 0.016 \\
\hline MAC 值 : 0.918 \\
\hline
\end{tabular}

※計測点配置 1 と重複したモード 1 の掲載を省略している.

る。また，14.9Hz（モード 9）と $18.6 \mathrm{~Hz}$ (モード 10）は各部材のモード振幅から, 高欄の部材振動モ

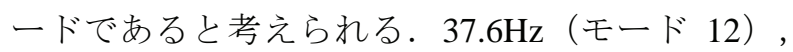
$52.8 \mathrm{~Hz}$ （モード 13）と振動数が高くなることで端 部のモード振幅が大きくなっていることがわかる. 他方で，131.0Hz（モード 14）は，中間スラブのモ 一ド振幅を勘案すると, 張出しスラブの部材振動モ ードではなく，中間スラブの部材振動（モード 6） に追従した疑似モードであると考えられる．以上の 傾向はいずれの列車走行試験でも確認された。なお, 次項の RC ラーメン高架橋を含め, 振動モードの同 定に際しては, 走行列車荷重の影響に留意する必要 がある。それらの詳細と対応策については 4. (1) で説明するが，本章に示す列車走行試験の同定結果 は，後に提示する対応策を経て算出していることを 断わつておく.

b) RC ラーメン高架橋

$\mathrm{RC}$ ラーメン高架橋を対象とした列車走行試験の
同定結果を表-10，表-11 に整理する。なお，計測 点配置 3 と計測点配置 4 でそれぞれ実施した 8 回, および 6 回の試験において，同定結果と走行列車の 速度や進行方向の列車諸元との間に有意な相関は確 認できなかった。また，いずれの計測点配置でも同 定されたモード 1 は表-10 に記載し，表-11 では省 略している。

列車走行試験では, 計測点配置 3 で 10 種類, 計 測点配置 4 で 6 種類の振動モード形をそれぞれ同定 可能であった。 中間スラブでは，インパルスハンマ 一試験と同様に，50.2 Hz（モード 4）以上の周波数 帯で部材の局所的な振動モードが同定されている. また，インパルスハンマー試験では同定できなかっ たモード 3 (全体たわみ 2 次 : 43.0Hz) や, モード 7 (中間スラブ橋軸, 橋軸直角 2 次 : $72.1 \mathrm{~Hz}$ ) 以上 の高次モードを同定可能であった。特に高次モード は複雑なモード形状を有するために, 低次モードと 比較して MAC 值が低下する傾向にあった。これに 
配慮して，高次モードの同定では理論モード形との 一致性を表すMAC 值の閾値を下げている.

張出しスラブと高欄でも，インパルスハンマー試 験と同様にモード $13(20.8 \mathrm{~Hz})$ で高欄の 2 次モー ドが同定されている，その他に張出しスラブと高欄 が連動した張出し部の振動モードも同定されている. 当該橋梁の張出しスラブと高欄は 3 枚のスラブによ り構成されている。 モード 11 からモード 14 までの 比較的低次の振動モードでは 3 枚のスラブが連動し た振動モードとなっているが，モード 15 では 3 枚 のスラブが隣り合うスラブとそれぞれ逆位相で振動 するモードが同定されている.

\section{(4) 同定結果の比較}

列車走行試験とインパルスハンマー試験の同定結 果を比較する. はじめに, 表-4 から表-11に示した 各橋梁の同一振動モード形に対する固有振動数（表 中に*印で記載）に着目寸る。両試験による差異は RC ラーメン高架橋のモード 1 (全体たわみ 1 次) が最大で, 約 20\%（両結果の差を平均で除した值） となっている. なお, RC 桁式高架橋では最大でも 15\%程度であった．列車走行試験で同定した固有振 動数の方が概ね祗い值であることから列車質量の影 響が考えられるが，いずれにしても顕著な差異はみ られない.さらに, 張出しスラブと高欄のみに着目 すれば，その差は最大でも $10 \%$ 程度である. 張出し スラブと高欄で固有振動数の差が小さい理由として, 当該部材に走行列車の輪荷重が直接作用しないこと があげられる. 固有振動数の変動係数に着目した場 合, インパルスハンマー試験ではいずれの橋梁でも ほとんどのモードで変動係数が $2 \%$ 程度となってい る. 一方で, 列車走行試験における変動係数は 2〜 8\%程度であり, インパルスハンマー試験ほどの安 定性は得られないことがわかる。また， RC ラーメ ン高架橋では列車走行試験の場合, 変動係数が 10\%を超える振動モードも存在する. RC ラーメン 高架橋については, 複線橋であったこと（加振箇所 が進行方向により異なる）, 採用した走行列車の速 度に $100 \mathrm{~km} / \mathrm{h}$ 以上の差が存在したことなどが影響し ていると考えられるが，原因を完全に説明できるよ うな規則性は確認できなかった。

つぎに，振動モード形に着目する，対象としたい ずれの橋梁でも, 同定可能なモード数は明らかに列 車走行試験の方が多い.MAC 值に着目した場合, 両試験でともに同定された振動モードの MAC 值は, 列車走行試験で同定された場合の方が大きく, 走行 列車荷重を用いた方が理論モード形に近い振動モー

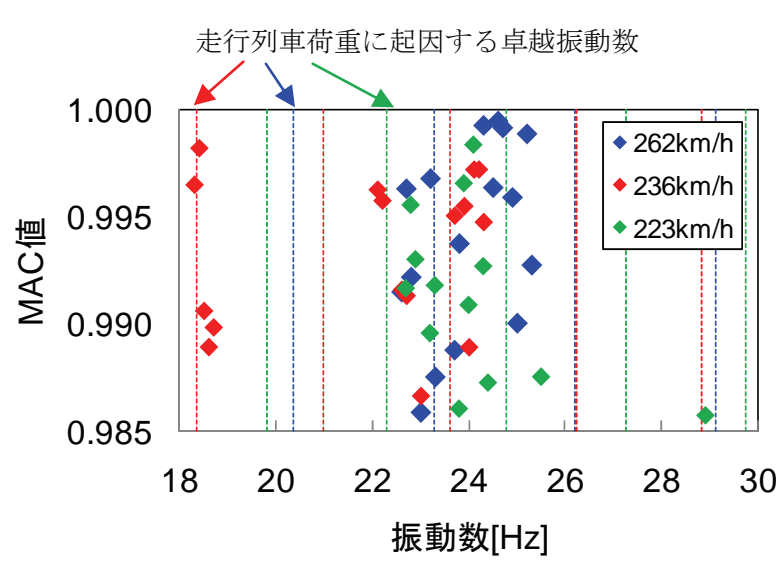

図-8 加振周期が振動特性の同定に及ぼす影響 （RC 桁式高架橋）

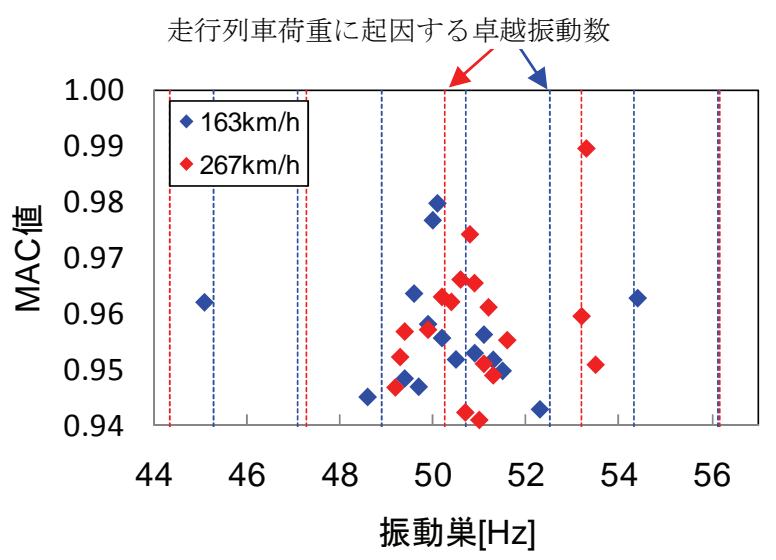

図-9 加振周期が振動特性の同定に及ぼす影響 (RC ラーメン高架橋)

ド形を励起可能であることがわかる。なお，RC ラ 一メン高架橋の全体たわみ 1 次である表-6 のモード 1 (25.6Hz) と表-10 のモード 1 （20.8Hz）では張出 しスラブの位相が異なっていたが，これは本研究で 採用したクロススペクトル法が比例減衰を仮定して いることに起因すると考えられる．実際に固有振動 数での張出しスラブ（計測点 25）の位相を確認す ると，インパルスハンマー試験でー $102.69^{\circ}$ ，列車 走行試験でー $85.31^{\circ}$ と近い值を示していることが わかる。

\section{4. 同定結果の信頼性}

\section{（1）走行列車荷重の影響}

本章では，2．（4）で指摘した，走行列車荷重を 用いた振動特性の同定に関する留意点として, 走行 列車の加振周期が同定結果に及ぼす影響を明らかに し, 経験的に獲得した対応策を述べる. 式(2)で表さ れる基本振動数の整数倍では, 構造物固有の振動と 
表-12 振動数の比較

\begin{tabular}{|c|c|c|c|c|c|c|}
\hline 橋梁 & 対象 & $\begin{array}{c}\text { 同定結果 } \\
(\mathrm{Hz})\end{array}$ & $\begin{array}{c}\text { 理論値 } \\
(\mathrm{Hz})\end{array}$ & $\begin{array}{c}\text { 部材長 } \\
(\mathrm{m}) \\
\end{array}$ & $\begin{array}{c}E \\
\left(\mathrm{kN} / \mathrm{m}^{2}\right)\end{array}$ & $\begin{array}{c}\text { 単位重量 } \rho \\
\left(\mathrm{kN} / \mathrm{m}^{3}\right)\end{array}$ \\
\hline \multirow{2}{*}{ RC 桁式高架橋 } & 全体たわみ 1 次 & 6.5 & 6.1 & $\lambda=19.1$ & \multirow{5}{*}{$2.65 E+7$} & \multirow{5}{*}{24.5} \\
\hline & 張出しスラブ 1 次 & 9.7 & 13.9 & $\lambda=1.9$ & & \\
\hline \multirow{3}{*}{ RC ラーメン高架橋 } & 全体たわみ 1 次 & 20.8 & 16.1 & $\lambda=8.1$ & & \\
\hline & 中間スラブ & 50.2 & 49.0 & $a=5.6 b=8.1$ & & \\
\hline & 張出しスラブ & 11.5 & 11.1 & $\lambda=1.9$ & & \\
\hline
\end{tabular}

※ヤング係数 $E$, 単位重量 $\rho$ は設計值を用いている.

は別に, 走行列車荷重の周期性に起因寸る振動数成 分が卓越する.この卓越振動数において構造物の振 動モードが存在しないにもかかわらず周期的な強制 加振により振動モード形と類似したモード形状が励 起された場合，クロススペクトル法では，これを振 動モードとして抽出してしまう。各橋梁における加 振源の周期性に起因した疑似モードの影響を図-8,

図-9 にそれぞれ示す．図-8 には，計測点配置 1 で 計測した速度の異なる 3 つの列車走行試験における モード 3 （全体たわみ 2 次十張出しスラブ 2 次）の MAC 值の分布を示している. 一方で, 図-9 には, 計測点配置 3 で計測した速度の異なる $2 つ の$ 列車走 行試験のモード 4（中間スラブ 1 次）の MAC 值の 分布を示している。 また, 同図中には式(2)で算出 される走行列車荷重に起因する卓越成分を列車ごと にそれぞれ点線（図-8，青：262km/h，赤：236km/h， 緑： 223km/h）（図-9，青：163km/h，赤： $267 \mathrm{~km} / \mathrm{h})$ で示している.

まず，図-8の RC 桁式高架橋を用いて説明する. 図中に赤で示す $236 \mathrm{~km} / \mathrm{h}$ で列車が走行したケースに, 加振周期の影響を見ることができる．当該ケースで は，いずれの列車速度の場合でも MAC 值が高くな っている $24 \mathrm{~Hz}$ 付近の他に, $18.4 \mathrm{~Hz}$ 付近でも MAC 值が高い振動数帯が存在する. 式(2)より算出され る基準振動数 $2.62 \mathrm{~Hz}$ の 7 倍に当たる $18.36 \mathrm{~Hz}$ と一 致していることから, 加振振動数の卓越により疑似 的に励起された振動モードであると考えられる。さ らに，列車速度が $236 \mathrm{~km} / \mathrm{h}$ のケースでは， $24.0 \mathrm{~Hz}$ の MAC 值よりも $18.4 \mathrm{~Hz}$ の MAC 值の方が大きいた めに, MAC 值最大を条件に振動モードを決定した 場合, 後者が固有振動数として同定され, 同定精度 が低下寸る．図-9 に示す RC ラーメン高架橋でも同 様の現象が見て取れる. 図中に赤で示す $267 \mathrm{~km} / \mathrm{h}$ で 列車が走行した場合では，振動モードと考えられる 50 51Hz 付近の他に, $53 \mathrm{~Hz}$ 付近にも MAC 值が高い 振動数が存在する. $53 \mathrm{~Hz}$ 付近は式(2)より算出され る基準振動数 $2.96 \mathrm{~Hz}$ の 18 倍に当たる. 列車速度が $267 \mathrm{~km} / \mathrm{h}$ の場合, $50 \mathrm{~Hz}$ 付近の MAC 值よりも $53 \mathrm{~Hz}$ 付近の MAC 值の方が大きいため, MAC 值最大を
条件に振動モードを決定した場合，RC ラーメン高 架橋でも固有振動数の同定精度が低下してしまう.

そこで本研究では, 速度の異なる複数の列車走行 試験結果を利用し, 列車の走行速度が変化しても MAC 值の分布が大きく変動しない振動モードのみ を構造物固有の振動モードとして同定することとし た。なお，前述したように3.（3）の同定結果はこ のような手順を踏んで算出している.

\section{（2）理論值との比較}

列車走行試験より同定した各橋梁の振動特性を理 論值と比較する。式(3), 式(4)，式(5)より算出した 各橋梁の全体 1 次たわみ，中間スラブ 1 次，および 張出しスラブ 1 次モードの固有振動数を表-12 に示 す。なお，中間スラブは部材振動の 1 次モードが同 定できていないために省略した，RC 桁式高架橋の 全体 1 次たわみモードでは，同定結果に理論值が良 く一致している. 張出しスラブでは同定結果の方が 約 35\%低くなっているが，表-9 のモード 7 （張出し スラブ 1 次）を見ると径間中央の主桁のモード振幅 が 0.4 程度となっており，端部固定の境界条件が正 確に成り立っていない可能性が考えられる，RC ラ ーメン高架橋の中間スラブ，および張出しスラブで は同定結果に理論值がよく一致しており，同定結果 の理論的妥当性を確認できる。一方で，全体 1 次た わみモードでは，境界条件を単純支持で算出してい るために，理論值が若干低い値となっている。なお， 境界条件を固定とした場合でも約 $30 \mathrm{~Hz}$ となり，全 体たわみ 1 次では対象径間のみならず，隣接する径 間，および柱の剛性の影響が大きいと考えられる.

つぎに，各橋梁の中間スラブと張出しスラブの 2 次以上の部材振動モードを対象として, 同定結果と 固有值解析結果を比較する. RC 桁式高架橋では中 間スラブ 3 次モードと張出しスラブ 2 次モードを例 として図-10 に示す。また，RC ラーメン高架橋で は中間スラブ 3 次モード， 5 次モード，および張出 しスラブの 2 次モードを例として図-11 に示す. 図10(a)に示した RC 桁式高架橋の中間スラブ 3 次モー ドは, 固有振動数, および振動モード形ともに表-8 


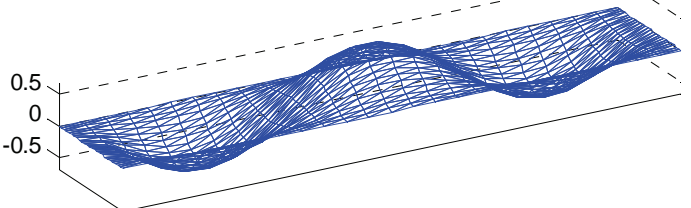

固有值解析 : $125.3 \mathrm{~Hz}$

同定結果：131.5Hz（表-8 中のモード6）

(a) 中間スラブ 3 次

固有值解析 : $28.4 \mathrm{~Hz}$

同定結果 $\quad: 24.4 \mathrm{~Hz}$ (表-9 中のモード 11)

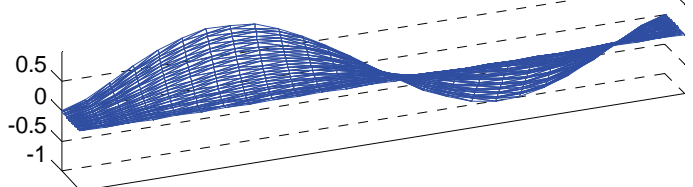

(b) 張出しスラブ 2 次

図-10 固有值解析結果（RC 桁式高架橋）

に示したモード 6（中間スラブ 3 次）とほぼ一致し ている。また，同様に図-10(b)に示した張出しスラ ブ 2 次モードは，表-9 に示したモード 11 (全体 2 次十張出しスラブ 2 次）に近い值となっており, 固 有值解析結果と整合的な振動モードが同定できてい ることがわかる。さらに，RC ラーメン高架橋にお いても，図-11(a)に示した中間スラブの固有值解析 結果は, 固有振動数, および振動モード形ともに表 -10に示したモード 6 （中間スラブ橋軸直角 2 次）， モード 7 (中間スラブ橋軸, 橋軸直角 2 次）とほぼ 一致しているとともに, 図-11(b)に示した張出しス ラブ 2 次モードは，表-11のモード 12 （張出し部 2 次）とほぼ一致していることが確認できる。

なお，本研究で用いた簡易なモデルではすべての 固有值解析結果と同定モードが一致しているわけで はない。これに対して, 列車走行や他部材まで含め た, より詳細な有限要素モデルを用いた動的解析に よって現象再現性に対する検討を別途実施している. それらにおいては，固有值解析結果と同定結果が一 致することを確認しているが，本研究の範疇を超え るために，別の機会に発表したいと考える。

\section{5. 走行列車と振動モード}

\section{(1) 列車走行時の卓越モ一ド}

列車の走行に伴い卓越成分を形成するような振動 モードを明らかにするために，列車走行試験より同 定した各振動モードとパワースペクトルを比較する。

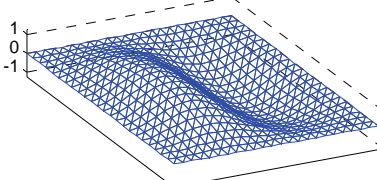

固有値解析 : $64.5 \mathrm{~Hz}$ 同定結果 : $63.6 \mathrm{~Hz}$

（表-10 中のモード6）

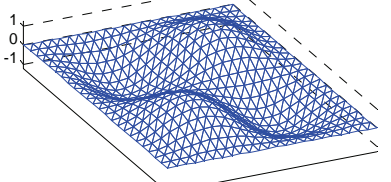

固有值解析 : $77.5 \mathrm{~Hz}$

同定結果 : $72.1 \mathrm{~Hz}$

（表-10 中のモード 7） (a) 中間スラブ 3 次, 5 次

\section{固有值解析 : $13.8 \mathrm{~Hz}$}

同定結果 $\quad: 13.4 \mathrm{~Hz}$ (表-11 中のモード 12)

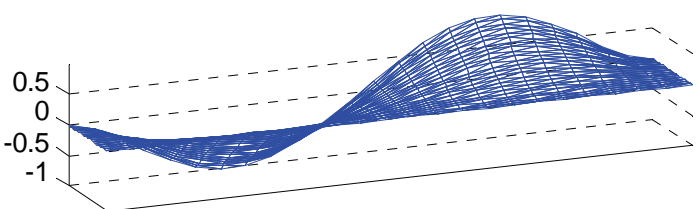

(b) 張出しスラブ 2 次

図-11 固有值解析結果（RCラーメン高架橋）

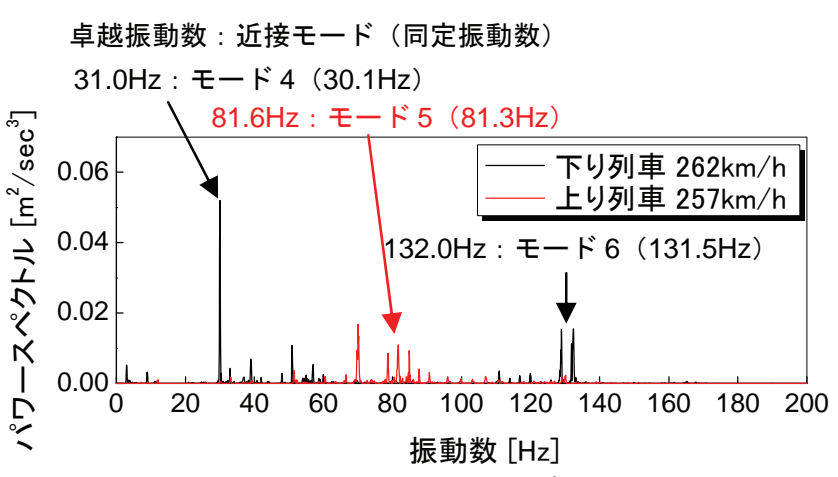

(a) 中間スラブ

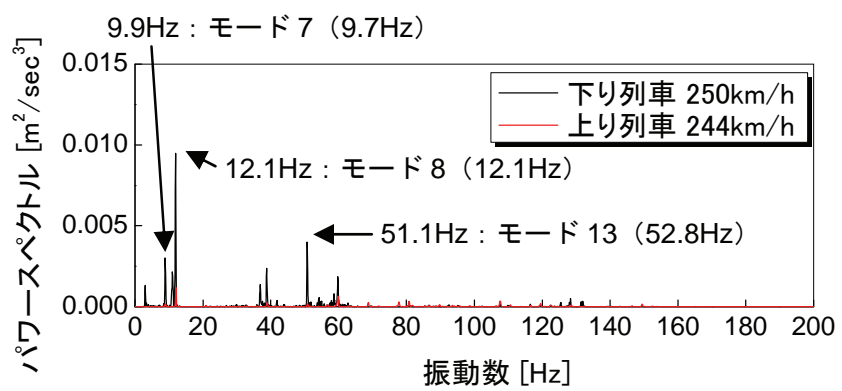

(b) 張出しスラブ，高欄

図-12 列車通過時のパワースペクトル

\section{a) RC 桁式高架橋}

図-12 に RC 桁式高架橋の各部材における上りと 下り列車通過時のパワースペクトルを示す。図12(a)は，中間スラブの卓越成分を検討するために, 計測点配置 1 で中間スラブ上の計測点 4，6，8，10 および 12 のパワースペクトルの平均值を，図一 12(b)は，張出しスラブ，高欄の卓越成分を検討す るために，計測点配置 2 で張出しスラブ上の計測点 


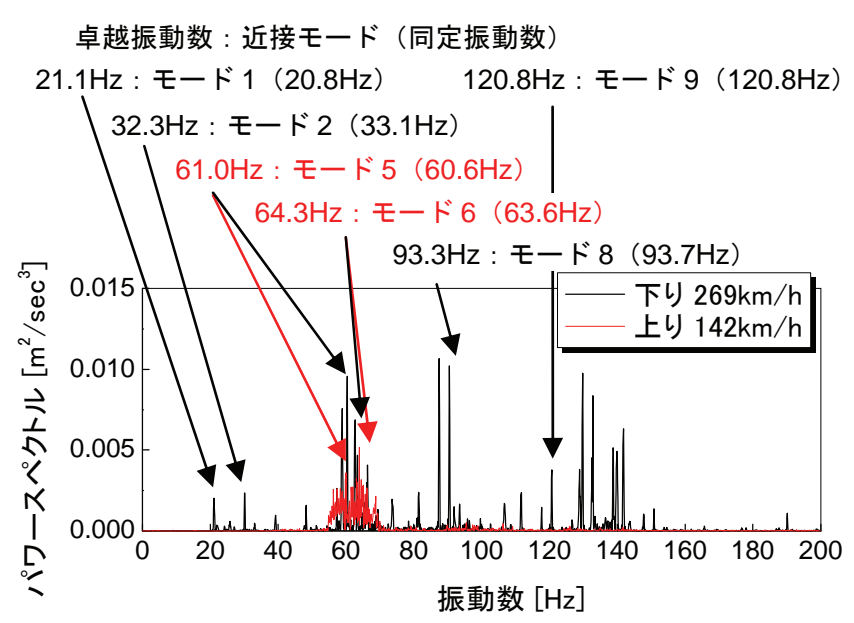

(a) 中間スラブ

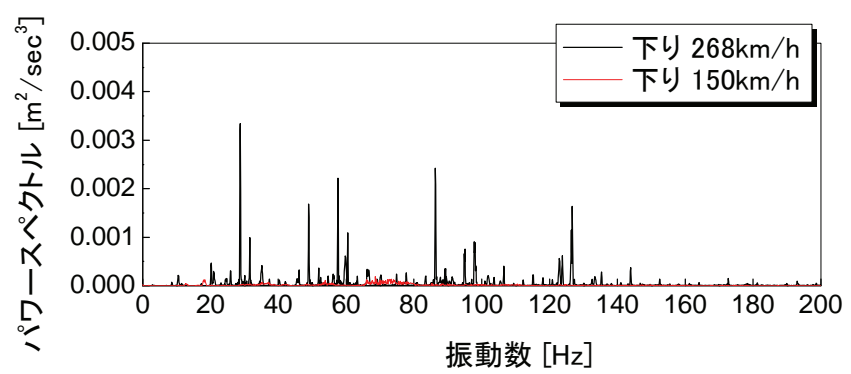

(b) 張出しスラブ，高欄

図-13 列車通過時のパワースペクトル

1，3， 5， 6， 11 および 15 のパワースペクトルの平 均值を示している. また, 主要な卓越振動数に近接 する振動モードを併せて記載している，なお，紙面 の都合上，複数の計測点のパワースペクトルを平均 として各図に記載しているが，各計測点のパワース ペクトルをそれぞれ確認した場合でも，以下に述心゙ る考察結果が変わらないことを確認している.

対象橋梁は下り線に位置するために, 直接荷重が 作用する中間スラブでは，下り列車通過時と上り列 車通過時の卓越振動数の分布が大きく異なっている. 一方で, 直接荷重が作用しない張出しスラブでは進 行方向の違いはスペクトル振幅にのみ現れ, 卓越振 動数の分布自体は同様である. 加振源である走行列 車に起因する卓越振動数が存在するため, 同定した 振動モードによりす心゙ての卓越成分を説明できるわ けではないが, 複数のケースにおいては列車走行時 の主要な卓越成分に構造物固有の振動が寄与してい ることがわかる.さらに，中間スラブでは部材振動 モードが同定されている $131.5 \mathrm{~Hz}$ に近接する $132 \mathrm{~Hz}$ で, 張出しスラブでは部材振動モードが同定されて いる $9.7 \mathrm{~Hz}$ に近接する $9.9 \mathrm{~Hz}$ で, ともに卓越成分を 確認することができる.

\section{b) RC ラーメン高架橋}

図-13(a)には，RC ラーメン高架橋における
$269 \mathrm{~km} / \mathrm{h}$ の下り列車通過時, および $142 \mathrm{~km} / \mathrm{h}$ の上り 列車通過時のパワースペクトルを示す．なお，中間 スラブでは列車の進行方向の変化に起因するスペク トルの変化がほとんどないことを確認している，一 方で, 張出しスラブと高欄では, 対象とした部材が 下り側であったために，上り列車が通過した場合と 比較して, 下り列車が通過した際にはスペクトル振 幅が数倍になることを確認した，そこで，図-13(b) には下り方向へ向かう $268 \mathrm{~km} / \mathrm{h}$ ，と $150 \mathrm{~km} / \mathrm{h}$ の列車 通過時のパワースペクトルを示している. 図-13(a) は，特に中間スラブの卓越成分を検討するために, 計測点配置 3 で中間スラブ上の計測点 $5 ， 7 ， 8 ， 12$, 16 および 19 の加速度パワースペクトルの平均值を, 図-13(b)は, 特に張出しスラブ, 高欄の卓越成分を 検討するために, 計測点配置 4 で張出しスラブ上の 計測点 $1 ， 4 ， 7 ， 11,16$ および 24 のパワースペク トルの平均值を示すとともに, 卓越振動数に近接す る振動モードを併せて記載している.

いずれの部材も列車の走行速度が速い方がパワー スペクトル振幅が大きい．図-13(a)の中間スラブは， ごの速度でも $60 \mathrm{~Hz}$ 付近で卓越成分を形成しており， その振動数からモード 5 (中間スラブ対角 2 次）と モード 6 (中間スラブ橋軸直角 2 次）の寄与が考え られる. $142 \mathrm{~km} / \mathrm{h}$ の場合, $60 \mathrm{~Hz}$ 付近が唯一の卓越 成分であるが，269km/h の場合では $90 \mathrm{~Hz}, 130 \mathrm{~Hz}$ 付 近など高振動数帯で多くの卓越成分を確認できる. 特にモード 8 (中間スラブ橋軸 3 次）の寄与が考え られる $93.3 \mathrm{~Hz}$ では高いスペクトル振幅を有してい る. 中間スラブでは高次モードの寄与の他に, 低次 にも一定のスペクトル振幅を有したピークを確認で きる.これらの卓越振動数ではモード 1 (全体たわ み 1 次），モード 2 (全体橋軸直角 2 次）といった 全体モードの寄与が考えられる，速度応答や変位応 答に換算する場合は振動数で除するために, このよ うな低次の卓越成分も重要となる。一方で, 列車走 行時の張出しスラブ, 高欄におけるパワースペクト ル（図-13(b)）では，前節で同定した固有振動数に 近接するような卓越振動数は確認できなかった。ま た, 約 $60 \mathrm{~Hz}$ や約 $90 \mathrm{~Hz}$ の卓越成分は中間スラブを 対象としたパワースペクトルでも確認できることか ら, 対象橋梁の列車通過時の振動では中間スラブや 全体振動の影響が大きいことがわかる.

\section{（2）部材振動モードの共振速度}

今後の高速化の状況によっては同定した振動モー ドで共振，および共振に起因する構造物音の発生が 懸念される，本節では各橋梁で同定した各振動モー 


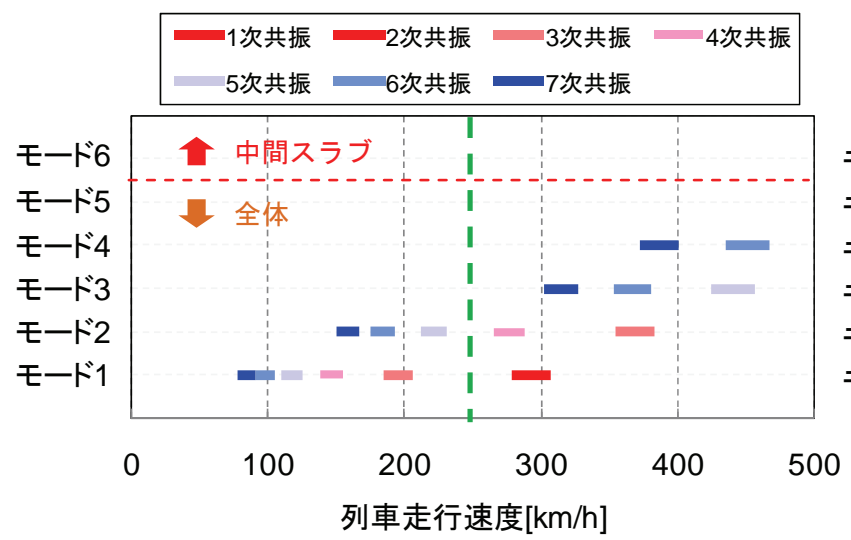

(a) RC 桁式高架橋 : 中間スラブ

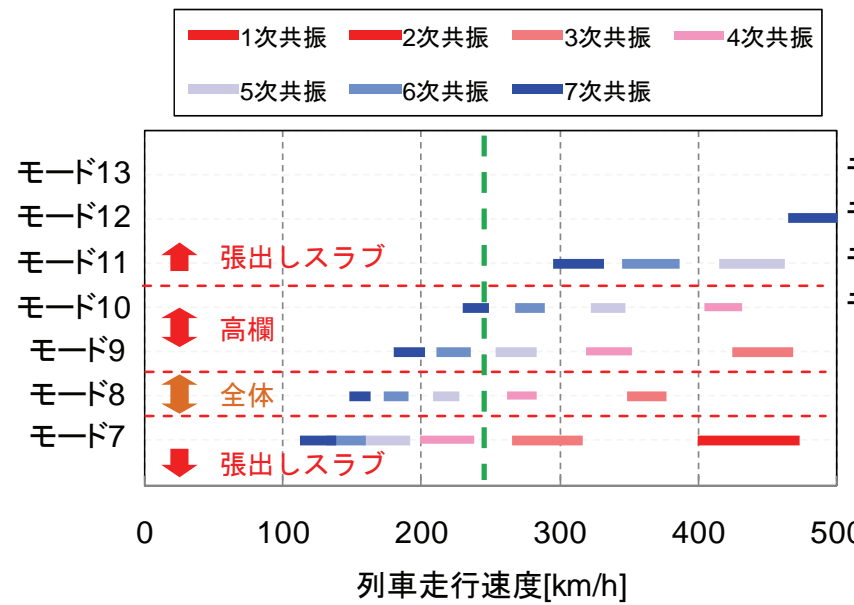

(b) RC 桁式高架橋 : 張出しスラブ, 高欄

図-14 各振動モードの共振速度（車両間隔）

ドの共振速度を式(2)に基づき算出し, 高速化に際 して留意が必要な振動モードを明らかにする。

\section{a) RC 桁式高架橋}

図-14 には同定した RC 桁式高架橋の固有振動数 から算出した各振動モードの共振速度を示している. なお，同定した固有振動数には変動係数で表される ばらつきが存在する．これを考慮し，共振速度を固 有振動数士標準偏差の区間として算出した. 7 次共 振までの共振速度を図中に示す， $L_{v}$ は車両長 $25 \mathrm{~m}$ を用いた. なお $n$ 次共振速度は 1 次の共振速度を次 数 $n$ で除すことで算出でき, 任意の加振から次の加 振までの間に $n$ 波の固有振動が励起される速度を表 す. RC 桁式高架橋においては $500 \mathrm{~km} / \mathrm{h}$ までに 1 次 共振が発生するような振動モードは存在しないこと がわかる. 図-14(a)のモード 1 (全体たわみ 1 次モ ード）が $280 \mathrm{~km} / \mathrm{h} \sim 300 \mathrm{~km} / \mathrm{h}$ で, 図-14(b)のモード 7

(張出しスラブ 1 次モード) が $400 \mathrm{~km} / \mathrm{h} \sim 470 \mathrm{~km} / \mathrm{h}$ で，いずれも 2 次共振の発生が懸念される. 固有振 動数が $131.5 \mathrm{~Hz}$ のモード 6 (中間スラブ 3 次）と固 有振動数が $51.1 \mathrm{~Hz}$ のモード 13 (張出しスラブ 5 次）では $500 \mathrm{~km} / \mathrm{h}$ までに 7 次以下の共振が発生しな いことがわかる。

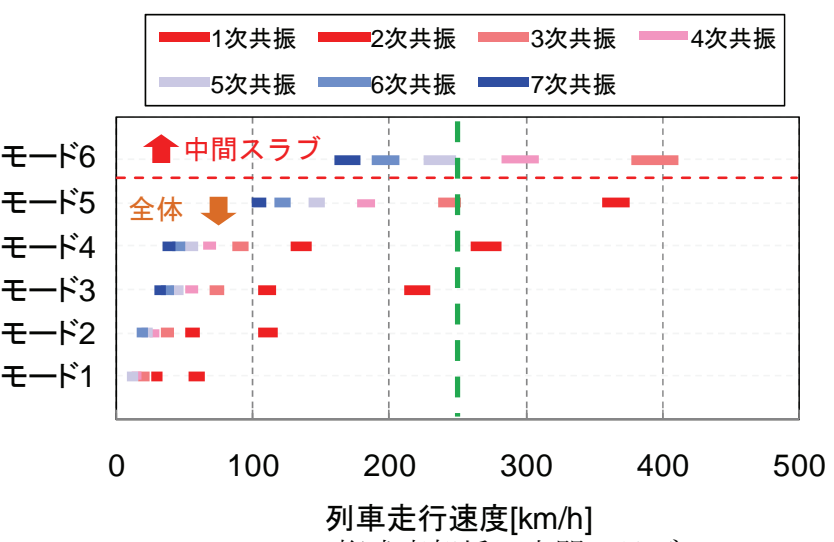

(a) RC 桁式高架橋：中間スラブ

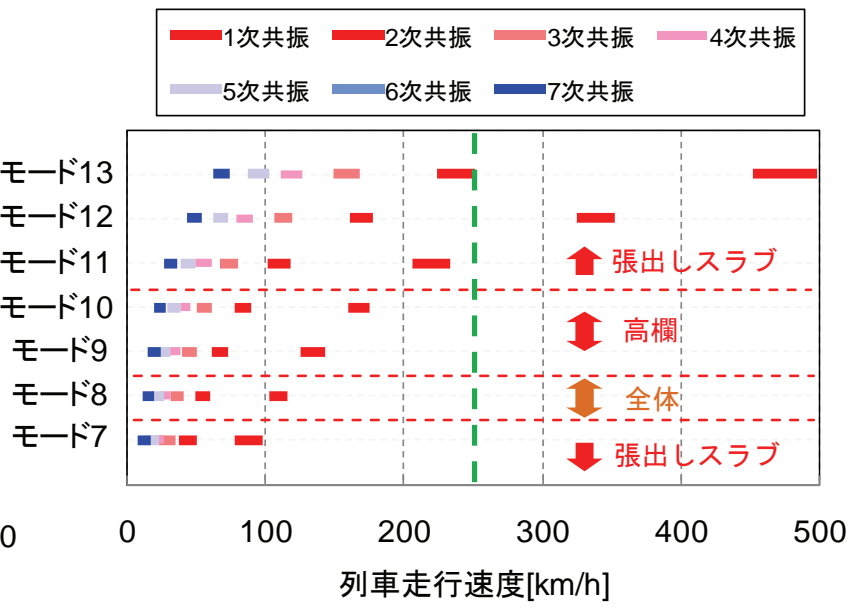

(b) RC 桁式高架橋 : 張出しスラブ, 高欄

図-15 各振動モードの共振速度（車軸間隔）

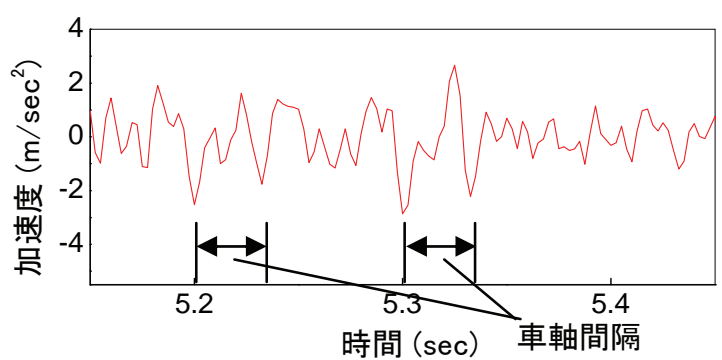

図-16 列車走行時の加速度応答（計測点 6)

一方で，図-12 では比較的高次の部材振動モード でも列車通過時に卓越成分を形成している。このよ うな高次モードでは，車両間隔のみならず車軸間隔 といった，より高周期の荷重間隔との共振の影響が 危惧される. 列車通過に起因する最も高周期の荷重 間隔として，車軸間隔 $2.5 \mathrm{~m}$ で算出した共振速度を 図-15に示す．RC 桁式高架橋のモード 6 (中間スラ ブ 3 次），およびモード 13 (張出しスラブ 5 次） は，ともに $240 \mathrm{~km} / \mathrm{h}$ 付近がそれぞれ 5 次，および 2 次の共振速度に該当する。 また, 図-12 で上り列車 通過時にのみ卓越成分を形成したモード 5 (全体 4 次）も $250 \mathrm{~km} / \mathrm{h}$ 付近が 3 次共振速度であり, 走行列 車の車軸間隔との共振により卓越した可能性を指摘 


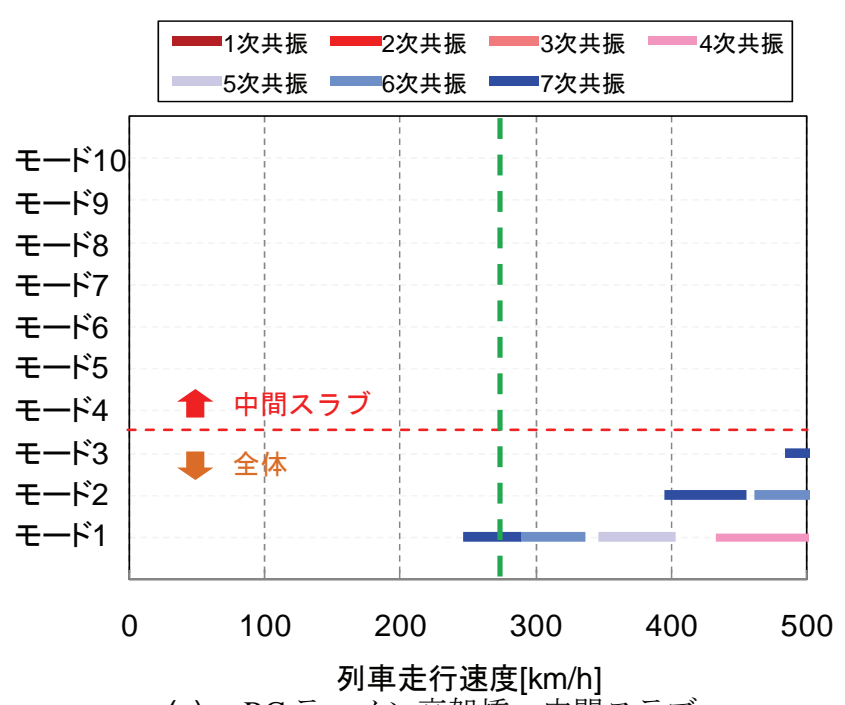

(a) RC ラーメン高架橋：中間スラブ

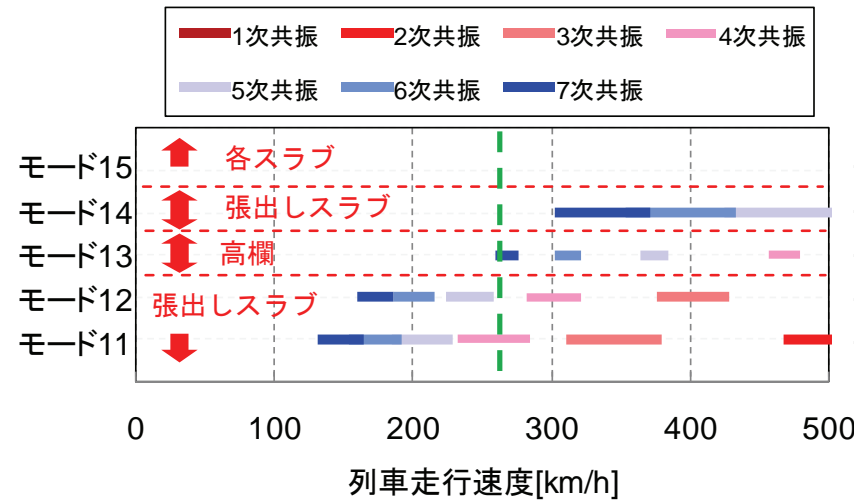

(b) RC ラーメン高架橋 : 張出しスラブ，高欄

図-17 各振動モードの共振速度（車両間隔）

できる．なお，台車間隔についても同様の分析を実 施したが，高周波数帯の部材振動モードとの低次

（1 次， 2 次）共振の発生は確認されなかった。

共振中の加速度応答の例として，計測点配置 2 で, 列車の通過速度がモード 13 (張出しスラブ 5 次) の 2 次共振速度に近い $250 \mathrm{~km} / \mathrm{h}$ で通過した際の計測 点 6 の加速度応答を図-16 に示寸. 加速度振幅から 列車車輪の通過を読み取ることができる. 同じ台車 の前の車輪が通過してから後の車輪が通過するまで の間隔に 2 波の振動を確認することができ, 実際に 2 次共振が発生していることがわかる。

b) RC ラーメン高架橋

図-17 には同定した RC ラーメン高架橋の固有振 動数から算出した共振速度を示している. なお, 前 項と同様に変動係数を考慮して，区間として算出し た共振速度を 7 次共振まで示すとともに， $L_{v}$ として 車両長 25m を用いている. 図-17(a)のモード 1 (全 体たわみ 1 次）では約 $430 \sim 500 \mathrm{~km} / \mathrm{h}$ で 4 次, 図17(b)のモード 11 (張出し部単純振動) では約 470 〜 $500 \mathrm{~km} / \mathrm{h}$ で 2 次の共振の発生が予測されるが，特

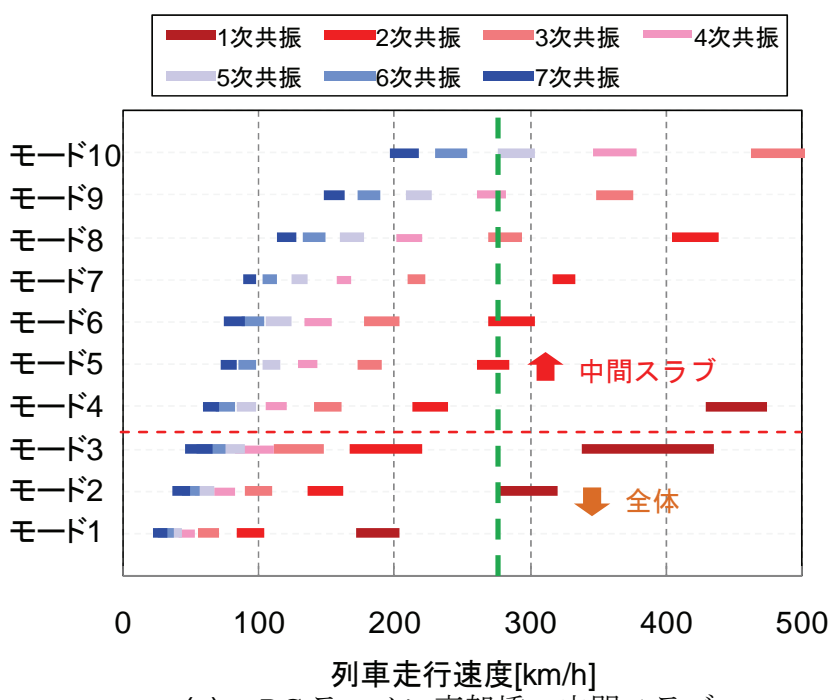

(a) RC ラーメン高架橋：中間スラブ

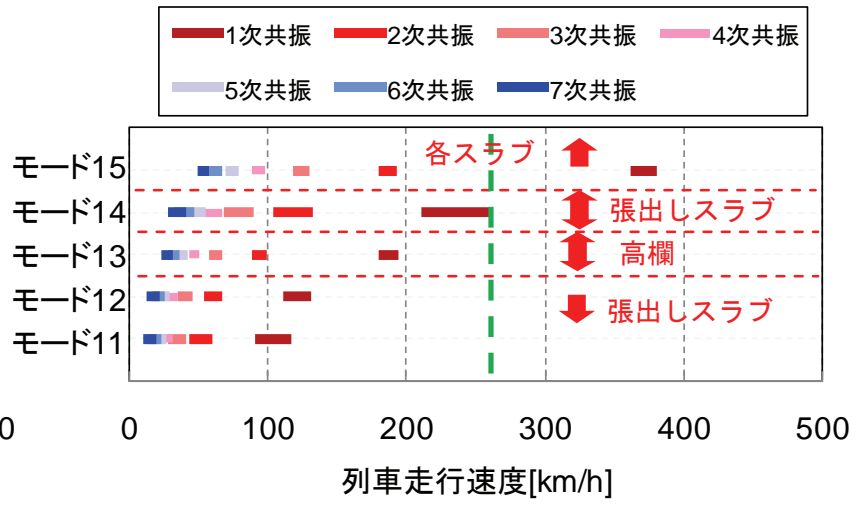

(b) RC ラーメン高架橋 : 張出しスラブ，高欄

図-18 各振動モードの共振速度（車軸間隔）

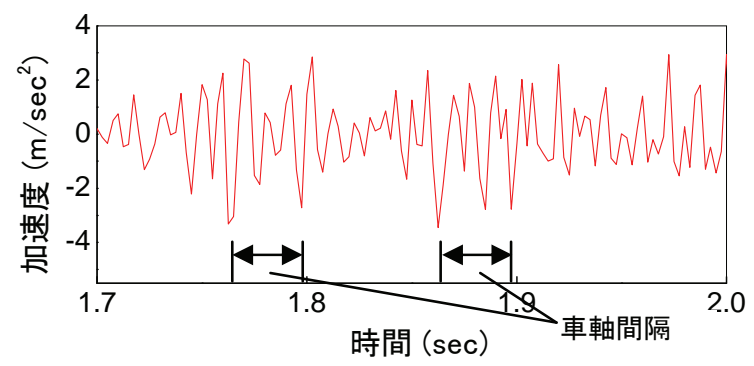

図-19 列車走行時の加速度応答（計測点 5)

に中間スラブでは部材振動の固有振動数が $50 \mathrm{~Hz}$ 以上であるために， RC ラーメン高架橋でも $500 \mathrm{~km} / \mathrm{h}$ までに 7 次以下の共振が発生しないことが わかる.

つぎに，車軸間隔による加振周期との共振の関 係を述べる．車軸間隔を $2.5 \mathrm{~m}$ として共振速度を算 出した結果を図-18 に示す. 図-18(a)から，RC ラー メン高架橋の中間スラブでは $200 \mathrm{~km} / \mathrm{h}$ 以上の列車速 度となることで，多数の部材振動モードで 2 次， 3 次共振の発生が懸念される, 実際に, 図-13(a)で卓 
越成分を形成したモード 5 （中間スラブ対角 2 次）， モード 6 (中間スラブ橋軸直角 2 次），モード 8 （中間スラブ橋軸 3 次），モード 9 （中間スラブ橋 軸 4 次）の各モードでは，列車通過速度の $269 \mathrm{~km} / \mathrm{h}$ が，それぞれ 2 次から 4 次の共振速度となっている. 一方で, 張出しスラブ，高欄を対象とした図-18(b) を確認すると, 本試験で用いた列車の通過速度であ る約 $260 \mathrm{~km} / \mathrm{h}$ はモード 14 (張出し部単純振動) の 1 次の共振速度に近接している. しかし, 図-13(b)で はモード 4 の固有振動数である $26 \mathrm{~Hz}$ 付近に卓越成 分を確認することはできない。

共振時の加速度応答の例として, 計測点配置 3 に おいて, 列車がモード 5 (中間スラブ対角 2 次）の 2 次共振速度に近い $269 \mathrm{~km} / \mathrm{h}$ で走行した場合の計測 点 5 の加速度応答を図-19 に示寸. 加速度振幅の大 きさから列車車輪の通過が読み取れるとともに, 同 じ台車の前の車輪が通過してから後の車輪が通過す るまでの間隔に 3 波の振動を確認することができ, 実際に 3 次共振が発生していることがわかる。

\section{6. おわりに}

本研究では, これまで未解明であった列車走行時 の RC 高架橋部材の動的挙動を把握し, 振動特性の 同定を行った．具体的には，代表的な RC 鉄道高架 橋である RC 桁式高架橋と RC ラーメン高架橋のス ラブ部材を中心として, 列車走行試験を実施し, 計 測した加速度応答を用いた振動特性の同定を行った。 その結果, 共振や構造物音の検討に必要な $200 \mathrm{~Hz}$ 程度までの局所的な部材振動モードを同定するに至 った. 本研究により得られた知見を具体的に以下に 示す.

1) 列車走行試験は, インパルスハンマー試験と比 較して, 多くの振動モードを同定できるととも に, MAC 值の高い振動モード形が励起されるこ とを確認した。 なお, 固有振動数の変動係数は 最大 $10 \%$ 程度とインパルスハンマー試験と比較 して若干大きくなることに留意する必要がある. 2) 走行列車荷重に起因寸る疑似モードを MAC 值 の比較に基づく提案手法により除外することで, 列車走行時の応答からクロススペクトル法によ り部材振動特性を同定できることを確認した。

3) 列車走行時の RC 桁式高架橋では, 約 $130 \mathrm{~Hz}$ で 中間スラブの 3 次モード, 約 $9 \mathrm{~Hz}$ で張出しスラ ブの 1 次モード, 約 $25 \mathrm{~Hz}$ で張出しスラブと橋梁 全体の連成 2 次モードなどの振動モードが励起
されるとともに, 多くの振動モードは単純なシ エルモデルを用いた固有值解析結果と一致した.

4) 列車走行時の RC ラーメン高架橋では, $50 \mathrm{~Hz}$ 以 上の周波数帯域で中間スラブの各部材振動モー ドが励起されるとともに, 中間スラブの部材振 動モードは固有值解析と比較的よく一致するが, 境界条件などが複雑な張出しスラブでは大きく 乘離する振動モードも確認された。

5) RC 桁式高架橋の部材振動モードと走行列車に関 しては, 列車速度が $240 \mathrm{~km} / \mathrm{h}$ 程度で, 車軸間隔 と中間スラブ 3 次モードや張出しスラブの 5 次 モードとの 2〜5 次共振の発生が懸念される.ま た，列車走行時のパワースペクトルから車軸間 隔との共振が懸念される振動モードで卓越成分 が形成されることを確認した。

6) RC ラーメン高架橋の部材振動モードと走行列車 に関しては, 列車速度が $260 \mathrm{~km} / \mathrm{h}$ 程度で, 車軸 間隔と中間スラブ対角 2 次や中間スラブ 4 次モ ードとの 2〜4 次共振の発生が懸念される.また， 列車走行時のパワースペクトルから車軸間隔と の共振が懸念される振動モードが卓越成分を形 成することを確認した.

一方で，今後の課題を以下に述べる。第一に，本 研究では, 標準設計に基づいて建設された 2 種類の 高架橋を対象とすることで, 高速鉄道路線を構成す る大半の高架橋の部材振動特性に関寸る知見を得た. しかしながら, 現在, 少数ではあるが, さらに低剛 性の RC 鉄道高架橋の建設も進められており, 今後, このような特殊橋梁の部材振動特性を把握していく ことが重要となる。第二に, 本研究で得られた列車 走行時の振動特性と騒音計測結果の比較がある。こ れにより, 実証的に構造物音を励起する振動モード 形を特定することで，効率的な対策方法を検討する ことが可能となる．また，並行して数值計算 ${ }^{13)}$ に よるメカニズムの解明を進めることで, 今後のさら なる列車高速化における構造物音の発生予測と対策 の必要性を議論することも重要である，第三に，本 研究で同定した振動モードを再現する有限要素モデ ルの構築に際しては, 固有振動数や振動モード形の 他に, モード減衰比が重要な指標となる。本研究で 採用したクロススペクトル法では，モード減衰比を 同定寸ることが困難であることから，ERA ${ }^{23}$ 法など， より高度な同定手法の適用により, 各振動モードの モード減衰比を把握することも重要な課題である.

謝辞 : 本研究の一部は文部科学省「若手研究者の自 立的研究環境整備促進」事業により大阪大学グロー 
バル若手研究者フロンティア研究拠点で実施された

\section{参考文献}

1) Fryba, L.: Vibration of solids and strucutures under moving load, Noordhoff International, 1972.

2) (財) 鉄道総合技術研究所 : 鉄道構造物等設計標準・同 解説一コンクリート構造物, 丸善, 2004.

3）松浦章夫 : 新幹線橋りょうにおける橋桁の鉛直たわみ の許容限度, 鉄道技術研究報告, No.894, pp.1-46, 1974.

4）曾我部正道, 松本信之, 藤野陽三, 涌井一, 金森真, 宮本雅章 : 共振領域におけるコンクリート鉄道橋の動 的設計法に関する研究，土木学会論文集，No.724/I-62, pp.83-102, 2003.

5）宮下剛, 石井博典, 藤野陽三, 庄司朋宏, 関雅樹 : $レ$ ーザー計測を用いた鋼鉄道橋の高速走行より発生する 局部振動の把握と列車速度の影響, 土木学会論文集 A, Vol.63, No.2, pp.277-296, 2007.

6）後藤晴夫 : 山梨リニア実験線でリニア車両の牽引走行 試験を開始, 土木学会誌, Vol.82, No.2, pp.44, 1997.

7）高速鉄道研究会 : 新幹線一高速鉄道の技術のすべて, 山海堂, 2003.

8）渡辺勉, 曽我部正道 : RC ラーメン高架橋の衝撃係数 に関する解析的検討，鉄道総研報告，Vol.24，No.4， pp.11-16, 2010.

9）原田和洋, 杉崎光一, 貝戸清之, 曽我部正道 : 鉄道橋 の動的応答における部材振動性状の簡易同定法, コン クリート工学年次論文集, Vol.30, No.3, pp.13-18, 2008.

10）長倉清 : 鉄道騒音問題の現状と展望, 日本音響学会誌, Vol.64, No.10, pp.624-628, 2008.

11）長倉清：構造物音の特性と低減対策, JREA, Vol.50, pp.51-53, 2007.

12）飯田雅宣：転動音・構造物音を予測する, Railway Research Review, Vol.67, No.7, pp.10-13, 2010.

13) 渡辺勉, 曽我部正道, 後藤恵一, 浅沼潔 : 構造物音評 価のための RC ラーメン高架橋の振動性状評価法，鉄 道力学論文集, 土木学会, Vol.14, pp.136-143, 2010.

14) 小笠原忠雄 : 山陽新幹線（岡山一博多間）技術のす心゙ て, 鉄道界評論社, 1975.

15) 国鉄新幹線建設局ほか：東北新幹線（大宮一盛岡間） 技術のす心゙て，鉄道界評論社，1982.

16) 原恒雄 : 東海道新幹線の高速化技術発展の足跡, 運輸 と経済, Vol.63, No.12, pp.32-44, 2003.

17) (財) 鉄道総合技術研究所: 鉄道構造物等設計標準 ・同 解説一耐震設計，丸善，1999.

18）松岡弘大, 貝戸清之, 杉崎光一, 渡辺勉, 曾我部正 道 : 走行列車荷重を利用した振動モニタリングによる 開床式高架橋の振動特性の同定, 応用力学論文集, 土 木学会, Vol.12, pp.983-994, 2009.

19）貝戸清之, 松岡弘大, 渡辺勉, 兽我部正道, 藤野陽 三：走行列車荷重下における鉄道橋桁の動的応答の特 性とその利用，土木学会論文集 F, Vol.66, No.3, pp.382-401, 2010.

20) モード解析ハンドブック編集委員会 : モード解析ハン ドブック，コロナ社，2000.

21）（社）土木学会 : 構造力学公式集, 博栄社, 1986.

22) 小松敬治 : 機械構造振動学, 森北出版, 2009.

23) 長山智則, 阿部雅人, 藤野陽三, 池田憲二 : 常時微動 計測に基づく非比例減衰系の非反復構造逆解析と長大 吊橋の動特性の理解, 土木学会論文集, No.745, pp.155-169, 2003.

\title{
IDENTIFICATION OF HIGH-ORDER LOCAL VIBRATION PROPERTIES OF RC VIADUCT UNDER THE PASSING TRAIN LOADS
}

\author{
Kodai MATSUOKA, Kiyoyuki KAITO, Tsutomu WATANABE \\ and Masamichi SOGABE
}

\begin{abstract}
As trains are getting faster rapidly, it is necessary to adjust RC railroad viaducts and their components for coping with structure noise. In this study, the authors conducted a train running test to grasp the vibration characteristics of the slabs of actual RC beam viaducts and RC rigid frame viaducts, in order to clarify the vibration characteristics of the components of RC railroad viaducts, which are necessary for evaluating and predicting structure noise. Then, it was found empirically that an RC beam viaduct has a vibration mode of the intermediate slab around $130 \mathrm{~Hz}$, and this mode becomes remarkable when a train passes. It was also revealed that in the case of an RC rigid frame viaduct, several vibration modes of the intermediate slab are excited in the frequency range over $50 \mathrm{~Hz}$ and the second-order mode of the middle slab becomes significant around $60 \mathrm{~Hz}$ when a train passes.
\end{abstract}

